\title{
An Overview of Plastic Waste Generation and Management in Food Packaging Industries
}

\author{
Lindani Koketso Ncube ${ }^{1, *(1)}$, Albert Uchenna Ude ${ }^{1}$, Enoch Nifise Ogunmuyiwa ${ }^{2} \oplus$, Rozli Zulkifli ${ }^{3} \oplus$ \\ and Isaac Nongwe Beas 4 (iD \\ 1 Department of Mechanical, Energy and Industrial Engineering, Faculty of Engineering and Technology (FET), \\ Botswana International University of Science and Technology (BIUST), Private Mail Bag 16, \\ Palapye, Botswana; udea@biust.ac.bw \\ 2 Department of Chemical, Materials \& Metallurgical Engineering Academic, FET, BIUST, Private Mail Bag 16, \\ Palapye, Botswana; ogunmuyiwae@biust.ac.bw \\ 3 Department of Mechanical and Materials Engineering, Faculty of Engineering and Built Environment, \\ The National University of Malaysia, UKM, Bangi 43600, Malaysia; rozlizulkifli@ukm.edu.my \\ 4 Botswana Institute for Technology Research and Innovation (BITRI), Private Bag 0082, Gaborone, Botswana; \\ ibeas@bitri.co.bw \\ * Correspondence: ncubelk@gmail.com
}

Citation: Ncube, L.K.; Ude, A.U.; Ogunmuyiwa, E.N.; Zulkifli, R.; Beas, I.N. An Overview of Plastic Waste Generation and Management in Food Packaging Industries. Recycling 2021, 6, 12. https://doi.org/ $10.3390 /$ recycling6010012

Received: 15 October 2020 Accepted: 30 December 2020 Published: 12 February 2021

Publisher's Note: MDPI stays neutral with regard to jurisdictional clai$\mathrm{ms}$ in published maps and institutional affiliations.

Copyright: (C) 2021 by the authors. Licensee MDPI, Basel, Switzerland. This article is an open access article distributed under the terms and conditions of the Creative Commons Attribution (CC BY) license (https:// creativecommons.org/licenses/by/ $4.0 /)$.

\begin{abstract}
Over the years, the world was not paying strict attention to the impact of rapid growth in plastic use. This has led to unprecedented amounts of mixed types of plastic waste entering the environment unmanaged. Packaging plastics account for half of the global total plastic waste. This paper seeks to give an overview of the use, disposal, and regulation of food packaging plastics. Demand for food packaging is on the rise as a result of increasing global demand for food due to population growth. Most of the food packaging are used on-the-go and are single use plastics that are disposed of within a short space of time. The bulk of this plastic waste has found its way into the environment contaminating land, water and the food chain. The food industry is encouraged to reduce, reuse and recycle packaging materials. A wholistic approach to waste management will need to involve all stakeholders working to achieve a circular economy. A robust approach to prevent pollution today rather than handling the waste in the future should be adopted especially in Africa where there is high population growth.
\end{abstract}

Keywords: food packaging; single-use plastics; plastic disposal; plastic waste management

\section{Introduction}

Food packaging has evolved to be a key aspect to successful food industries serving fast foods, ready meals, on-the-go beverages and snacks among others [1]. In 2019, there was an estimated 7.7 billion people in the world and by 2050, this figure is expected to reach 9.7 billion [2] with food supplies needed globally projected to increase by 50\% [3]. This growth in global population is driving increased demand for food production and consequently the increase in food packaging materials usage. Food packaging serves to safeguard food from external factors grouped into physical, chemical and biological [4,5]. Since ancient times, humans have found benefit from the use of polymers. Plastics have emerged as the most versatile polymer material successfully integrating into our daily lives [6-11]. The term plastic was derived from "plasticus" a Latin word derived from "plastikos" a Greek term that was used early in the 17th century for describing something able to be moulded or fit for moulding [12]. They have unique properties, high functionality and relatively low cost and different types have been used in different forms for various applications including food packaging [13-16]. Plastics possess high strength to weigh ratio. This results in minimal material usage when making packaging containers with the packaging material accounting for up to 3\% of the packaged product weight [17]. From the global plastic waste, packaging is the biggest contributor accountable for almost $50 \%$ 
of the total weight [18]. High income countries have generated more plastic waste per capita as compared to middle and low-income countries as consumers have more spending power thus can purchase a variety of plastic packaged products. However, with the advent of plastic waste management systems, the mismanaged plastic waste from developed countries is beginning to be on the decline. This has left middle and low-income countries becoming the main sources of global plastic pollution as there are poor or no plastic waste management systems resulting in up to $90 \%$ of plastic waste being inadequately disposed [19].

The 1940s witnessed the beginning of production of plastics on an industrial scale, and ever since then plastic waste generation has increased [20]. The challenge of rising amounts of plastic waste was first realised in the 1970s as a result of growing consumption. Particularly in fast food industry which easily provides food products timeously. There are many fast food outlets in the world today and as a result, waste amounts from this industry are increasing. Most of the waste from this industry was traditionally thrown away in landfills and the majority of this solid waste produced is packaging waste [21]. After plastic packaging materials have served their purpose, the bulk of them are disposed and become post-consumer waste [22,23]. This waste can find its way into recycling plants, incinerating plants, landfills or the environment [20]. In landfills and the environment these discarded plastics may persevere for very extensive periods of time determined by the composition of the plastic and the environment type and conditions in which they are disposed. Plastics present a wide range of problems when they enter the environment. They may clog sewers, provide breeding ground for mosquitoes and disease-causing pests, get ingested, choke and/or entangle animals, leak toxic materials, and find their way into the human food chain [18].

Sustainable development emerged so that there can be preservation of resources available in the present day to ensure that the same benefit and opportunities are available for exploitation in the future. This sustainability concept has brought about the need to avoid and/or diminish waste amounts, popularise the reuse concept, and incentivise recycling of products at their end of life [24]. Traditional food plastic packaging solutions are generally based on linear economies [25] and as such their continued use will lead to the depletion of nonrenewable resources, emission of greenhouses gases during manufacture and transportation, and as well as the generation of solid waste. The food industry is characterised by the reliance on using single use plastic packaging in high volumes. As a result, there is dire need of design and use of sustainable packaging solutions, as well as packaging waste disposal management.

It is worth noting that many reviews have discussed the challenges presented by the use of plastics. This current work seeks to present a detailed summary of consolidated key aspects of food packaging plastic waste management beginning from the production of plastics, their usage and disposal, and focuses on the reduce, reuse, and recycle concepts to achieve a circular economy. It also presents an update on the plastic waste management situation in Africa, a continent feared to contribute more plastic food packaging waste in the future.

\section{Packaging}

In the modern world, packaging of goods is essential from their inception, through their processing and handling right up to the end of their lifecycle. In developed countries, packaging accounts for about $2 \%$ of the gross national product and the majority of packaging materials is used in the food industry [26]. In the year 2000, the global packaging market was at USD 383 billion and is expected to reach USD 980 billion in 2020 [27]. Materials used in packaging serve to preserve, protect, merchandise, market and distribute foods in a cost effective manner to the satisfaction of industry and consumers as well as minimise negative impact on the environment $[28,29]$.

Packaging solutions are a product of years of design improvements where some developments were by unintended luck. In the early years, humans would consume food 
at the source and the societies were self-sufficient and only made or caught what they used and thus materials for packaging were not needed [30]. When the need for packaging came, nature provided the first materials to be used for packaging in the form of hollowed logs, woven grasses and animal organs [30,31]. Newer materials with unique shapes were used for specific needs as civilisation developed, these materials included ceramics, glass, metal and paper [31]. Packaging materials can be either rigid or flexible. Rigid packaging includes bottles, jars, cans and tins, whilst flexible packaging includes plastic films, papers, foil, cloth and sacks.

\subsection{Types of Packaging}

There are three types of packaging namely primary, secondary and tertiary [29,32-35];

1. Primary packaging is one that is in direct contact with products and will be handled by the consumer.

2. Secondary packaging groups individual units (primary packages) together for transportation and can be designed to be shelf-ready where it can display primary packaging for advertisement in retail outlets.

3. Tertiary packaging is for storage and handling of the secondary packaged products.

\subsection{Plastic Packaging}

The packaging industry requires materials that are lightweight so as to reduce the amount used to package a product, thus reducing product weight for transportation cost savings as well as reducing amount of end of life packaging waste material. Plastics have managed to fulfil this role very well and have remained unchallenged. As an example, one study by Marsh [36] revealed that the replacement of glass bottles with plastic bottles for beverage packaging in airlines resulted in savings of over USD 1 million in fuel costs as a result of the weight loss.

Fossil fuels are the main raw material used in the manufacture of plastics and in 2009 it was reported that up to $8 \%$ of world oil is channelled towards their production with $50 \%$ of it serving as feedstock and the other $50 \%$ as fuel for the conversion process $[6,17]$. In 2019, 10 years later, $10 \%$ of global oil production was used for plastic production with $40 \%$ of it dedicated to making single use plastics [37]. The annual growth of plastics consumption shows that the estimated global plastic consumption by 2050 will be standing at 500 million tonnes of which single use products will be the major consumer [38,39]. The most used polymers for packaging are thermoplastic accounting for $84 \%$ of the plastic market share $[36,40]$. The following Table 1 shows some uses of thermoplastics in packaging of food.

Petroleum based polymers which include polypropylene (PP), polystyrene (PS), polyvinylchloride (PVC), polyethylene (PE) and polyethylene terephthalate (PET) have been used extensively for packaging as a result of their light weight, good mechanical performance, good barrier properties among many other properties [41-43]. Many of these end up in landfills where they take centuries before they degrade [44]. They are responsible for a great amount of environmental pollution as they are nonbiodegradable $[40,45]$.

The packaging industry has begun using recyclable plastics in their designs as a means of reducing waste disposed into the environment. However, recyclers must maintain contaminants in the reformed plastic to sufficiently low levels acceptable for intended use of the resulting packaging [31]. This has proved difficult, time consuming and costly since the collected plastic waste consists of different plastic types that have to be sorted and separated. After which, the plastic wastes may have to be washed clean to remove the different contaminate residues from products they were packaging [22]. Additionally, plastic additives such as the popular phthalates have been shown to be persistent in recycled plastic and continue posing health problems as they have low molecular weight and can easily migrate from plastics into packaged food or water [46]. 
Table 1. Food packaging application from thermoplastics. Adapted from [41].

\begin{tabular}{|c|c|c|}
\hline Thermoplastic Material & Abbreviation & Packaging Application \\
\hline Polyethylene Terephthalate & PET & $\begin{array}{l}\text { Water/juice/soft drink bottles } \\
\text { Food jars } \\
\text { Microwavable containers } \\
\text { Plastic films }\end{array}$ \\
\hline Polypropylene & PP & $\begin{array}{l}\text { Drinking bottles } \\
\text { Bottles for milk } \\
\text { Food containers }\end{array}$ \\
\hline Poly vinyl chloride & PVC & $\begin{array}{c}\text { Plastic bags } \\
\text { Frozen foods stretch films } \\
\text { Container lid }\end{array}$ \\
\hline Polystyrene & PS & $\begin{array}{c}\text { Take away clamshells } \\
\text { Meat trays } \\
\text { Bottle caps } \\
\text { Straws }\end{array}$ \\
\hline Low density polyethylene & LDPE & $\begin{array}{c}\text { Disposal cups } \\
\text { Plates } \\
\text { Spoon } \\
\text { Bread bags }\end{array}$ \\
\hline High density polyethylene & HDPE & $\begin{array}{c}\text { Custom packages } \\
\text { Grocery bags } \\
\text { Water/milk/juice containers } \\
\text { Cereal and snack liners }\end{array}$ \\
\hline
\end{tabular}

\section{Food Packaging Waste}

There are high amounts of food packaging waste entering the environment causing pollution. Snack food packaging is one good long term case of a visually irritating example of environmental pollution [47]. Most food packaging plastics culminate in waste streams within a short time after purchase especially for single use packaging applications used in short lived goods $[6,15,22,46]$. This is as a result of an increase of on-the-go consumption of food and drinks that is driving the growth of single use plastic packaging [48,49]. In some locations, the challenge of low availability of bins can lead to increased littering [14]. A large proportion of food packaging plastics easily end up in open spaces as litter, municipal waste, landfills and even in oceans, whilst a few can be recycled. This is as a result of the human throw away culture [50] which is more prevalent in developing countries. When consumers purchase food on-the-go, after consuming they more often throw away the packaging at any location where they finished eating or drinking the packaged food. This culture can also be linked to social trends and individual behaviours which can be quite complex to deal with. Waste collection systems are seemingly failing to deal with waste resulting from this culture. Poor waste management systems also compound to this problem or nonexistence of enforcements or absence of substitute materials [41].

Globally, there are low recycling rates for single-use plastic packaging materials with only $14 \%$ of plastic packaging being collected for recycling and only $5 \%$ of it being successfully recycled into new plastic [51,52]. The common single-use plastic packaging waste materials polluting the environment in order of quantity include drinking bottles, bottle caps, food wrappers, grocery bags, lids, straws, stirrers and foam take away containers $[18,53]$. The food industry is encouraged to adopt the reduce, reuse and recycle waste control options rather than adopt the easy direct disposal method. This waste that is disposed in landfills results in methane gas creation, a greenhouse gas that surpasses carbon dioxide by more than $2000 \%$ in causing global warming [54].

Global plastic waste generated in 2015 had packaging contributing about 50\% [18]. This figure has remained high with food packaging estimated to be more than a third of the world total packaging market [55]. A $12 \%$ annual growth is being experienced by the food packaging industry raising more environmental concerns including greenhouse gases and greater carbon footprints [56]. Annually, Europe alone produces 23 million tonnes of plastic 
packaging and current projections will see 92 million tonnes by the year 2050 [3]. The European union has championed amendments to directives of packaging waste to demand that $75 \%$ of it be recycled by the year 2030. A comparative lifecycle study to investigate the extent of recycling that can yield favourable impacts on the environment has been done [57]. Results showed that recycling can greatly reduce environmental burdens posed by food packaging waste. Therefore, to deal with food packaging waste, there is need for integrated waste management schemes that can sustainably control waste generation without compromising the needs of the society and those of the environment.

\section{Plastic Waste Disposal}

After their use, products made from plastic can be disposed, recycled or incinerated. Up to 1980, almost all of plastic waste was discarded as recycling and incineration were negligible [19]. Incineration as a method for plastic waste management started growing from 1980 and in 1990 recycling started to be appreciated as well. In 2015, approximately 6300 million tonnes of cumulative plastic waste had been generated and about $9 \%$ was recycled, $12 \%$ was incinerated, and $79 \%$ was accumulated in landfills or in the natural environment [20]. From these three routes of plastic waste disposal, incineration was the only permanent route of eliminating the waste and this thermal treatment involves combustion.

Most synthetic plastics that are disposed in nature have a very unreasonably slow degradation process that takes long periods spanning hundreds to thousands of years $[18,54,58-60]$. When plastics are thrown away by consumers, some are blown off by wind to cover more area and some are washed away by rains to even find their way into water bodies. Plastics are one of the biggest pollutants of oceans [10,61-65]. Living creatures like sea animals, birds and livestock have even been affected by the plastic waste that is being dumped in water bodies and on land. Figure 1 displays the cumulative plastic waste generated and disposal.

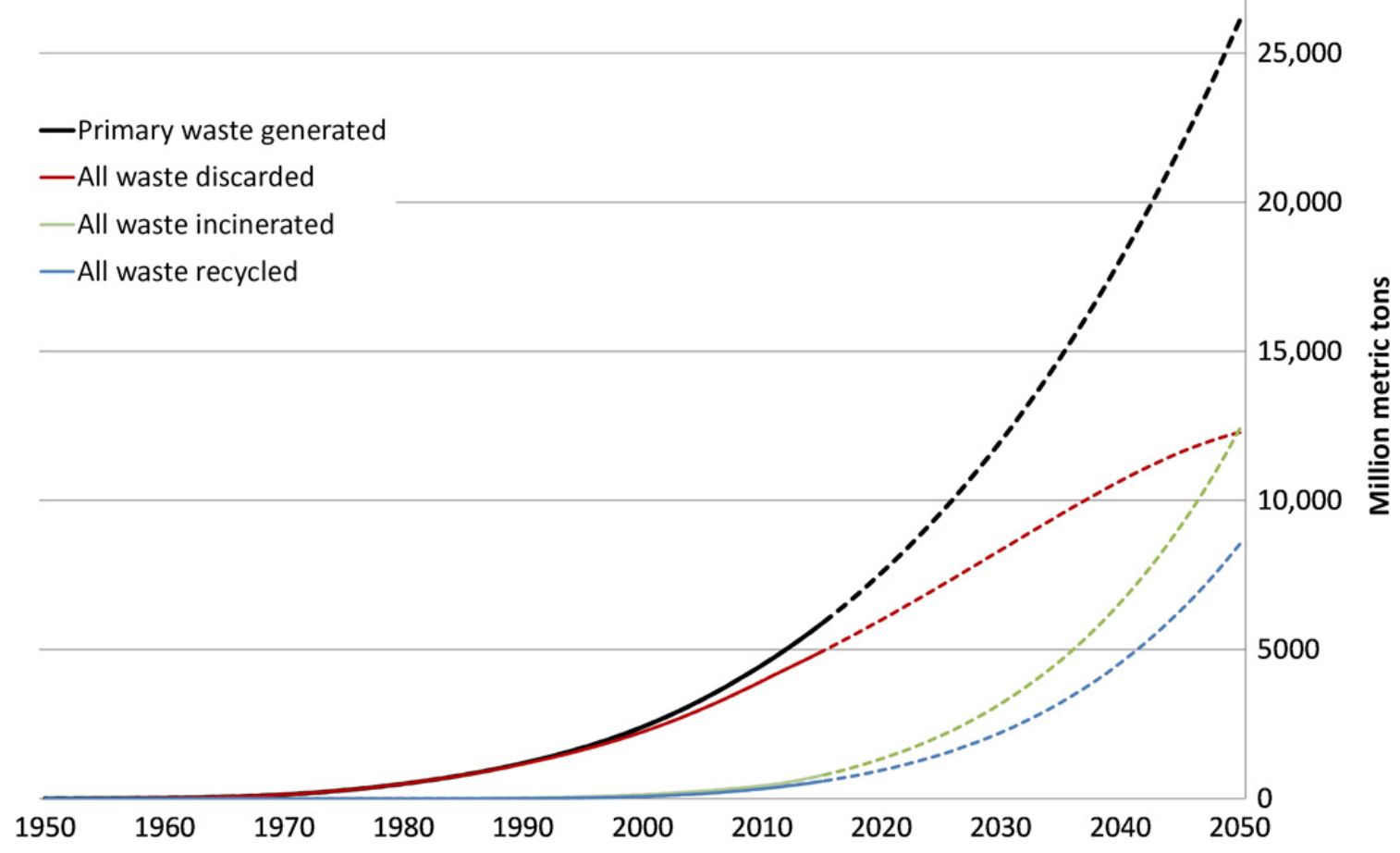

Figure 1. Generation and discarding of plastic waste [20] (Available online: https://creativecommons.org/licenses/by-nc/ 4.0/ (accessed on 25 November 2020)).

The solid lines show historical data from 1950 to 2015 whilst dashed lines show projections up to the year 2050 based on historical trends. Following these projections, 
environmental pollution with plastic waste is set to rise to alarming levels. Pollution from plastics is a global challenge requiring a complete paradigm shift on how to produce, use and dispose of plastics [66].

\section{Management of Food Packaging Plastic Waste}

Packaging plastics have a short lifecycle ranging from a day up to 3 years $[67,68]$. Examples of 1 day lifespan include disposable cups, plates and take away containers which can be referred to as single-use plastics. Several strategies from plastic ban, taxes, extended producer responsibility to recycling have been used in the management of plastic packaging waste. Given the fact that a dramatic amount of plastic packaging is still in use to date, recycling is a very important method that can contribute positively to the alleviation of plastic packaging waste pollution. Collecting, sorting and processing are the three main steps of the food packaging recycling process carried out under strict monitoring to prevent contamination $[69,70]$.

In the attempt to recycle plastics, chemicals added during plastic production including the finishes like dyes for printing and coatings present unique challenges [6,51]. In addition, recycling of food packaging plastics also requires the waste plastics to be clean from food contaminants as well as desorption is required of any food substances that may have found a way into the packaging polymers. Plastic recycling processes are largely focused on primary and secondary recycling methods thereby calling for growth in adoption of other recycling processes to improve the recycling capacity and efficiency [71]. It is worth noting that as the plastic waste is continually recycled using these methods, it loses its physical and chemical properties resulting in low quality end products warranting incineration at this point $[41,54,71]$. Recycled plastics of good quality would cost $60-70 \%$ of the price of virgin plastic but this value drops as properties are compromised from repeated recycling [72].

The food and drug administration (FDA) has noted with concern the recycling of plastics for food contact packaging [1,73]. As such, these primary packaging plastics may be best incinerated or chemically recycled. Secondary and tertiary packaging have less material variation and thus are easily sorted for recycling or reuse unlike primary packaging that is assorted, contaminated and habitually damaged and hence presents problems in sorting, recycling and reuse $[8,25,74]$.

In comparison, developed countries generally have better plastic management policies, for example in Europe, recycling and energy recovery rates have increased over the past decade resulting in reduction of landfilling [22]. The packaging sector in Canada has the highest plastic waste recovery rate [67]. Whilst developing countries do not have waste infrastructure to cope with the rising plastic waste [51].

The fate of global plastic packaging materials is depicted in Figure 2 which shows that most of the packaging waste ends up in the environment. This high amount of unrecycled plastic packaging is a cause for concern. The impacts can be reduced by sustainable waste management systems that recover materials and energy [55]. 


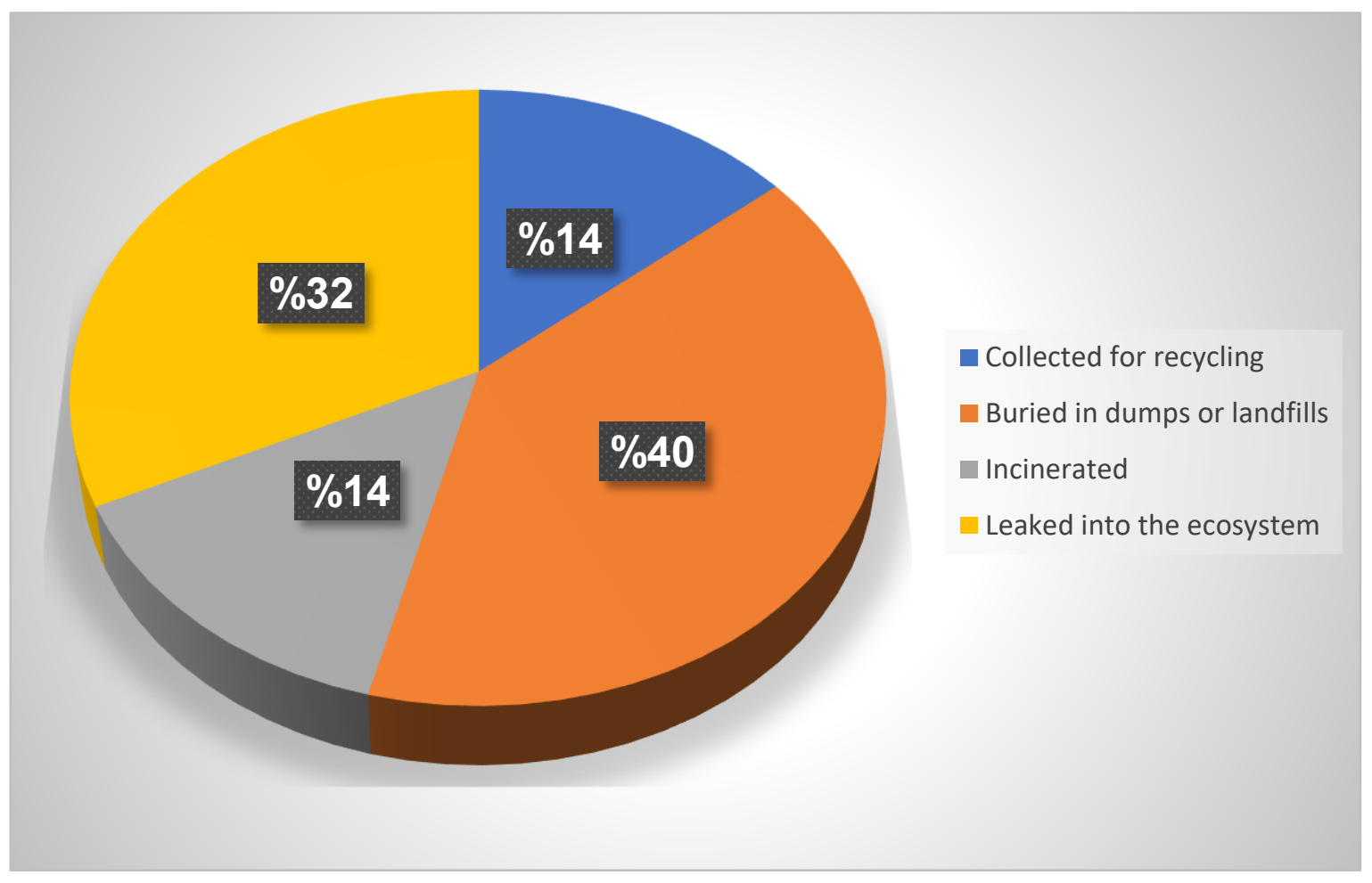

Figure 2. The fate of plastic packaging materials. Data from [51,75].

\subsection{Collecting and Sorting}

In recycling of plastics, the first and most important steps are collection and sorting. Plastic waste is generally collected through "bring schemes" and kerbside collection [68]. Sorting involves the selection of waste which is suitable for recycling using manual or automated means. This can be done at the source of the waste and by using separate collection systems or at facilities by mechanical processing and sorting of mixed waste [76]. It is reported that the recycling industry is operating at $40 \%$ capacity due to lack of differentiated collection and separation at source that affects the raw material supply [67]. Thus, packaging sorting plants have a crucial role in waste management and material recovery systems [76]. There are several techniques that can be applied to separate and sort plastic solid waste and these should be applied in the most efficient way during a short period of time so as to be cost effective [6,77]. Different machines including near-infrared (NIR) sorting machine can be used in new plants together with colour or induction sensors [76]. More techniques can employed for sorting that include laser-induced breakdown spectroscopy, triboelectric separation, $\mathrm{X}$-ray fluorescence, Fourier transformed infrared technique and froth flotation method $[11,54]$. Another upcoming promising technique for monitoring the separation of plastic waste and process quality information is ultrasound technology [11].

Plastic waste comprising mixed plastic types is difficult to recycle and not cost effective [17]. Additionally, intensive sorting technologies are not economically attractive [78]. For recycling to be effective, source separation and separate collection of the waste are the best routes to follow [76,79]. Food packaging waste sorting right from household waste at source forms a crucial part of waste management systems $[55,80]$. A study by Nemat et al. [81] showed that food packaging design possesses the potential to influence consumer behaviour when making decisions on disposal post use, however current food packaging is not adequately doing so. Through properly communicating to the consumer, packaging can convey specific information with regards to separating and sorting of the packaging post use. Household waste comprises several mixed products of different types, shapes and colours. Black plastic food packages are not easily detected by sorting machines 
as a result of the carbon black that makes them invisible [67]. This is because most sorting technologies for household plastics use NIR [80] and carbon black, the most common black colourant for plastics, absorbs NIR [70].

The quality of the feedstock material into recycling has a bearing on the suitable recycling process, efficiency of recycling, quality and application of the resultant product. Food packaging plastic waste can be characterised using four levels as shown in Figure 3 in order to determine the recycling route. Visual inspection can be done to identify the product type. Polymer identification and food contact labelling can be useful tools to separate the wastes. Technologies can also be utilised to identify the polymers so as to separate the wastes. The different sorting methods have been widely used and are now being investigated for optimisation [71]. State of the art sorting technologies have proved capable to process mixed waste of sizes as small as $2 \mathrm{~mm}$ [11].

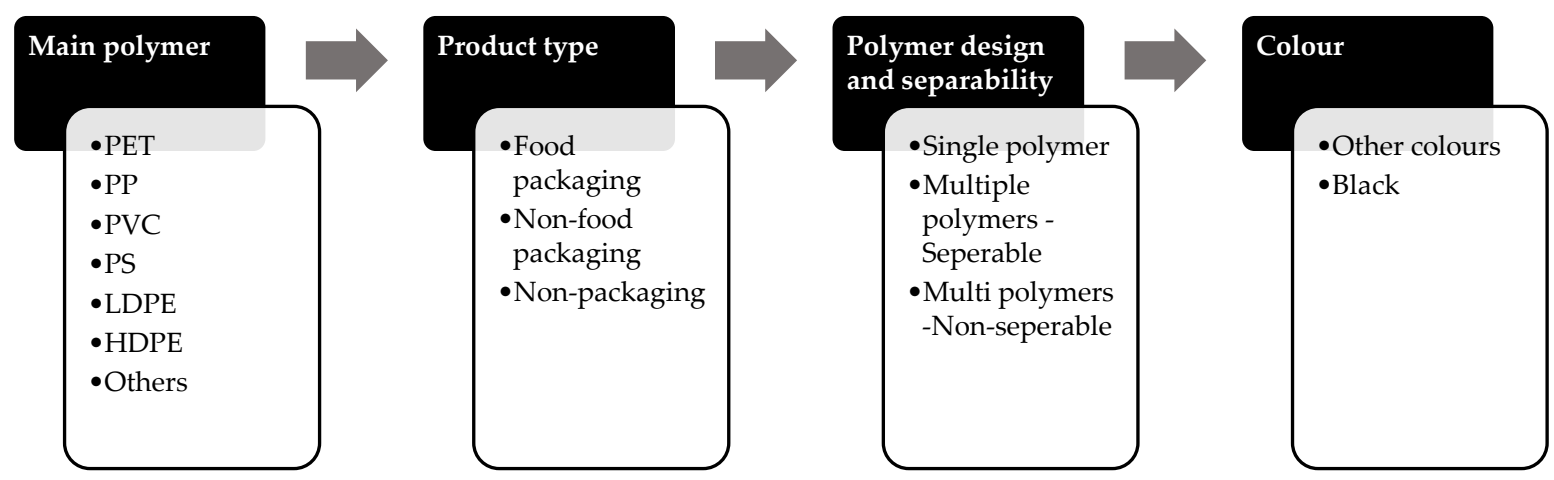

Figure 3. Four levels of plastic waste characterization for recycling. Data from [80].

Germany is developing a tracer-based sorting for post-consumer packaging waste [82]. They are employing trivalent lanthanide elements to serve as photoluminescent tracer materials that have bright emission lines in green, red, and NIR when subjected to electromagnetic irradiation. These tracer elements are applied in the part per million application range directly on the packaging material or in printing inks used on labels. This technology will outperform current NIR sorting capabilities as it can separate food from nonfood packaging even if they are all made from the same polymers. This will go a long way in improving recycling rates. It is important to separate food packaging waste from nonfood related products as they do not adhere to mandatory requirements expected of packaging thus can compromise the quality of recycled products [80].

\subsection{Reducing Materials}

The reduce principle aims at lowering the material quantities used in products and processes [25]. It is also referred to as downgauging [68]. In food packaging, this translates to the reduction of the amount of material used to make a package but still maintaining the optimum function of the packaging. Material reduction principles can result in packaging products with considerably lower environmental impacts [83]. Packaging reduction should be carefully carried out not to compromise the overall product system [84]. Coca cola has managed to reduce the material used in making bottles and is now making use of redesigned smaller bottles with shorter necks [51]. The target is to eventually make $100 \%$ recyclable packaging by 2025 [78]. In addition, their plastic usage comprises up to $10 \%$ recycled plastics [51] and this figure is projected to rise to $50 \%$ in 2030 [78].

In addition, the reduction of use of nonbiodegradable materials and uptake of biobased biodegradable polymers for food packaging plastic material is a viable option with so much research interest and potential to yield a sustainable circular economy in food packaging [33,85-94]. 


\subsection{Reusing}

This involves the use of discarded plastic packaging waste for several more times [95]. Source reduction by lowering demand and consumption of virgin raw materials can be achieved by reusing packaging material which otherwise would have been disposed [96]. This is the most preferred route as it involves less energy and resources to carry out [6]. Through reuse, waste materials can find a secondary route to obtain value rather than be disposed [41]. Reusable plastic packaging can also give the benefit of reducing packaging cost and can be used for primary, secondary and tertiary packaging [97]. The packaging can be reused as many times as it can retain its functional requirement before it is disposed or recycled. However, reused plastic packaging may be contaminated from their use as such, to avoid migration of contaminants to food during reuse packaging may be washed first [73]. As a result, the reuse principle is not very common for primary packaging [25].

A study by Del Borghi et al. [84] on food crates made from different materials showed that by using the life cycle assessment (LCA) the multiuse plastic crate had better environmental performance if it was reused many times. The LCA was done according to product category rules for crates for food using environmental indicators and impact categories that included global warming potential, cumulative energy demand, human, marine and terrestrial toxicity. Another study by Popovic et al. [98] developed a reusable X-bin container to replace wooden crates and single-use packaging. The success of the reuse model in primary food packaging is largely dependent on consumers as it requires a change in habits [25]. In real life applications, reusable and disposable packaging both generally present advantages and disadvantages with regards to environmental emissions, cost and logistics complexity. Thus, some food packaging application scenarios may require a compromise. A biobjective model was proposed by Bortolini et al. [99] that can provide a quantitative method to optimise the forward and reverse logistics of multipackaging of fresh fruits and vegetables. The model can minimise costs and environmental impacts in the fresh food supply chain network. A trial of the model in the Emilia-Romagna region in Italy yielded results that proposed a mix of reusable and disposable packaging containers at a ratio of $47.7 \%$ to $52.9 \%$, respectively, so as to achieve optimum results that saw a carbon dioxide emission saving of $45.1 \%$. However, further research is needed to create models that also consider the social dimension and effect on the product quality presented by the packaging choices.

\subsection{Landfilling}

This is the conventional waste management approach [7,100-102]. Studies report municipal solid waste (MSW) generation would rise from 2.4 billion tonnes in 2018 up to 2.6 by the year 2025 [103]. Plastics form a significant portion of MSW and these plastics include a considerable amount of packaging waste [54].

Landfilling is the worst waste management strategy [68] although is it considered indispensable for accommodating nonrecyclable and noncombustible waste [96]. Most plastics end up in the environment as landfills and this is highly undesirable as they can follow greener recycling routes. Landfill space is also becoming limited and expensive. Packaging plastics disposed of into landfills have poor biodegradability and generate explosive greenhouse gases such as methane [104]. Over the years, legislative pressures have and still demand that the waste to landfills must be reduced until there is no waste that is thrown away.

\subsection{Re-Extrusion}

This is the primary recycling of plastic solid waste which is a closed loop method that feeds plastic scrap into the extrusion process. This method is often used by industries to recycle polymer waste from their production process as it is easily identifiable and the waste is generally uncontaminated [105]. The recovered plastic is made into goods with similar performance to those from virgin plastics [72]. The recycled plastic is generally made into a product that serves the same function as the original plastic [11,106]. However, the quality of the scrap reintroduced has a bearing on the performance of the resulting 
product. The process becomes almost impossible to carry out effectively and efficiently as it requires clean or semiclean scrap, strict scrap sorting so not to mix different plastics and this increases the cost of the process and thus compromises its effective application $[6,54]$.

Closed loop recycling primarily depends on the inertness of the polymer and as well as on the sorption properties and diffusion behaviour of a polymer which will affect the interaction between the packaging and the product [73]. Clear bottles and milk bottles from PET and HDPE polymers, respectively, are the primary materials that were first identified to be recovered [68,107]. However, HDPE is more difficult to clean and is prone to sorption of contaminants [108]. Clear PET is more widely recycled for reuse in food contact application as a result of development of super clean grades of PET [109]. The recycling feed stream usually receives up to $5 \%$ of nonfood PET as a result of the collection systems and in some instances it can go up to $20 \%$, however, it does not pose a risk to the consumer as was assessed on the basis of Threshold of Toxicological Concern and Cramer classification tools [110]. Other polymers presenting appropriate properties for reuse in packaging are polyethylene naphtholate (PEN) and rigid PVC [73].

It is generally a simple process and popular among manufacturers utilising technologies such as injection moulding [54]. Another downfall of this process is the limit in number of cycles a material can be processed [73]. Nanoadditives are being looked into to eliminate the impact recycling has on the physical-mechanical properties of recycled polymers [75]. Many nanoadditives have been investigated including nanocellulose, zinc oxide, titanium dioxide and silicone dioxide resulting in improvements of the resultant nanocomposites for food packaging. Additionally, nanoparticle migration is generally below the limit allowed for food contact material opening up opportunities for increase in uptake of nanomaterials in producing packaging materials from recycled food packaging plastic waste.

\subsection{Mechanical Recycling}

Recognized as secondary recycling, also, is a process of reusing plastic waste in plastic manufacture using mechanical means. It can be carried out successfully when using single polymer plastics only $[6,111]$. The recovered plastic makes products with inferior performance characteristics compared to virgin plastics [68,72]. As such, the recycled plastics are made into different products from those which the original plastic was used to make $[11,106]$. As an example, the primary recovered polymer PET can be processed to give PET fibres, and HPDE from milk bottles can be converted to make crates and bins [68]. Additionally, PP is another widely used polymer in consumer applications including food packaging where it has found application in making yogurt containers that can be recycled to make consumer products like toothbrushes [112].

The steps involved in secondary recycling include cutting/shredding, contaminant separation, floating, milling, washing, drying, agglutination, extrusion and quenching. Virgin polymer and/or additives may be added to the recycled material during the grinding and melting stages [41]. It can make use of readily available plastic processing methods like screw extrusion and blow moulding [54]. Mechanical recycling is a low cost process and thus ideal for developing countries [113]. It is also the most favoured currently $[22,78,114]$ as it is efficient [73]. However, it shares the same disadvantage as primary recycling of polymers having a limited number of cycles [73].

Studies are ongoing to improve properties of mechanically recycled food packaging materials. As an example, blends of virgin and recovered PET were investigated by Masmoudi et al. [115] to achieve an optimum blend that can be used in food contact applications. After mechanical recycling, rheological analysis showed degradation results with PET decreasing in viscosity. Blending recycled PET to virgin polymer showed improvement of mechanical and thermal properties with an optimum blend comprising $30 \%$ recycled and $70 \%$ virgin PET. The migration tests performed on the blends proved they can be used for primary food packaging as they conformed to the EFSA standard. 


\subsection{Biological Recycling}

This applies chiefly to biodegradable plastics that have recently attracted consideration. Biological recycling is a form of tertiary recycling also described as organic recycling [68]. The biodegradable plastic industry is still small but growing [7]. These plastics can be attacked by microbes and broken down within short periods of time, thus entering the biological cycle. Biodegradable plastics are envisioned to find successful application in food or catering industries $[3,104]$. However, users may be misled to carelessly throw away more of the biodegradable packaging material into the environment and thus increasing plastic litter. There is carelessness in marketing of biodegradable or compostable plastics with some of them proving to have grave impacts on the environment as do nonbiodegradable petroleum based plastics $[51,116]$. Food packaging alternative materials should be analysed so as to assess their effect on the entire product system [84]. A mixture of biodegradable plastics with nondegradable plastics will pose further sorting and waste management problems.

It is reported by Kosior Mitchell [70] that biobased products may not be effectively handled by current end-of-life waste management options. Only drop-in bioplastics which can be used with current technologies are seen as ideal and these include bio-PE, bio-PP and bio-PET. However, other biobased polymers like polylactic acid can be used alone or with organic fillers to make compostable food packaging composites presenting opportunities for green packaging materials that can be biologically recycled. Compost bins may be used to allow for home composting of biodegradable food packaging waste [79]. However, care must be taken to note some products require industrial composting and will not compost in home composting conditions. For example, polylactic acid polymer has been widely believed to easily biodegrade in landfills or home composts or even in aquatic environments. This is not true as the polymer does require an industrial composter and as such should be referred to as compostable [116-120].

Some natural and designed microbes are reported by Drzyzga and Prieto [121] to be showing potential for possible application to biodegrade problematic petroleum-based plastics. Another new field of study reported is in the use of enzymes engineered for plastic degradation. Studies of PET, LDPE, linear-low density polyethylene (LLDPE) have been carried out. Further research is envisioned in the biological recycling field to employ microbes, fungus and enzymes in the degradation of plastics.

\subsection{Chemical Recycling}

Branded as tertiary or feedstock recycling as well, here the plastic polymers are broken down into individual useful components such as monomers. This means there is chemical modification of the polymer structure to generally produce liquids and gases to be used as feed material in the creation of other petrochemicals and plastics. Tertiary recycling contributes to the principle of energy sustainability as it generates raw materials that were made to create the plastic in the first place [54]. Chemical recycling offers the advantage of handling mixed and contaminated polymers with little pretreatment [6].

In feedstock recycling, pyrolysis has received notable attention as it offers operational and environmental advantages as well as financial benefits [122]. This is generally a thermochemical process that makes use of temperature, pressure and time to achieve desired hydrocarbons although the effect of pressure is reported to be not well documented by Al-Salem et al. [122] presenting a future research gap. There are many other methods of chemical recycling that include cracking, gasification, hydrolysis, glycolysis and chemical depolymerisation $[54,73]$. However, chemical recycling may be unworthwhile for developing countries as it is capital intensive and presents operational challenges [41]. Catalytic pyrolysis presents better advantages over the thermal process $[106,122]$ and there is a need to research catalysts used by this method to improve the overall efficiency and reduce energy demand of the process by lowering operational temperatures [11,71]. It is limited mainly to condensation polymers mostly for PET [73]. 


\subsection{Energy Recovery}

Energy recovery is also referred to as quaternary recycling. This is the burning of waste to attain or recover energy in the form of heat, steam and electricity. It can serve to address the global challenges of increasing energy consumption and plastic waste generation per capita [103]. Plastics derived from crude oil possess high calorific value and are thus sources of energy, for example, polyethylene, polypropylene and polystyrene have $44.9,46.5$, and 41.9 mega joules per $\mathrm{kg}(\mathrm{Mj} / \mathrm{kg})$ calorific value whilst petroleum has $42.5 \mathrm{Mj} / \mathrm{kg}$ [104].

After repeated recycling of plastics using primary and secondary recycling methods that result in the loss of their desired properties, they are discarded into landfills thereby contaminating the earth [54]. The general approach at this point is the combustion of the waste material thereby boosting energy supply [103]. Additionally, incineration of waste results in volume reduction of up to $99 \%$ and the residue can then be landfilled. Care must be taken as some air pollutants are emitted during incineration which include greenhouse gases and carcinogenic substances $[6,100,123,124]$.

Several Waste-to-Energy (WTE) technologies can be utilised for energy recovery. These technologies can be thermal (incineration, pyrolysis and gasification), biochemical (biomethanation/anaerobic digestion and fermentation) and chemical processes (esterification) [125-127]. WTE technologies are capital intensive and have mostly been established in developed nations and are yet to gain popularity in developing nations including African cities [128]. In developing countries, plastic waste can be used to start fires when cooking using wood thereby serving as a route for reducing plastic waste at household level but at the expense of harmful by-products emissions. Energy recovery via thermochemical energy recovery route can be further divided into incineration, gasification and pyrolysis technologies [103]. Incineration technologies are showing increased advancements and the main incinerator types are the grate or moving grates, rotary kilns and fluidised bed [103]. Plastic waste from food packaging generally gets mixed with other wastes to comprise MSW which finds its way to incinerators. WTE technologies when used for electricity generation had efficiency of $25-30 \%$, however, improvements to cogenerate heat and electricity have seen the efficiency rise to $80 \%$ [103]. Modern incinerators have been equipped with state-of-the-art air pollution control technologies to minimise the emitted air pollutants [106].

\subsection{Policies and Incentives for Managing Plastic Waste}

Governments worldwide have generally struggled for many years to reduce plastic waste $[16,51,65,129,130]$. Plastic recycling has attracted a lot of legislative attention unlike any other recycling business [82]. Different policies and incentives can be looked at to ensure the timely capture and sorting of packaging waste for recycling and these include extended producer responsibility (EPR), taxes and bans [67]. The responses from countries varies widely in their policies and implementation of systems meant to remedy plastic waste. This has resulted in recycling of only $9 \%$ of the 9 billion tonnes of cumulative worldwide plastic waste reported in 2018 [18]. In 2019, Jefferson [37] reported the figure to have reached $10 \%$ and that it would continue to rise slowly.

As a result of the intricate recycling system for plastics, manufacturers generally avoid investing in plastic recycling [78]. The EPR policy holds the manufacturers to be responsible for the life cycle of their produced packaging material. As such, manufacturers are motivated to design green materials and increase awareness on handling of their product throughout its service life up to the material recovery stage thereby forming a closed loop cycle. EPR is still lacking in Africa and in southern Africa, it is under implementation only in South Africa [67].

Extra charges like taxes can be imposed on packaging material to deter irresponsible use of the materials. The most recycled polymer is PET and Norway is reported by Maria and Leva [67] as holders of the world record of having the highest PET bottle recycling rates standing at $97 \%$. This is attributed to a redeemable fee that is charged when purchasing a 
PET bottle to discourage the throw away culture. In the United Kingdom a tax was levied on carrier bags and resulted in consumers opting to reuse the bags rather than buying more and this resulted in almost 16 billion less bags used by the consumers [70].

Plastic bans seem to have been a more widely used policy to manage plastic waste. Several countries have introduced regulations on plastic bags and Styrofoam products. However, based on the experience of more than 60 countries, there is not much information to draw conclusive information on the impacts of the bans [131]. This could be attributed to the failure of enforcing the regulations for one reason or another [131,132]. Inevitably, the problem of plastic pollution would persist. The following Figure 4 shows the impacts of the bans.

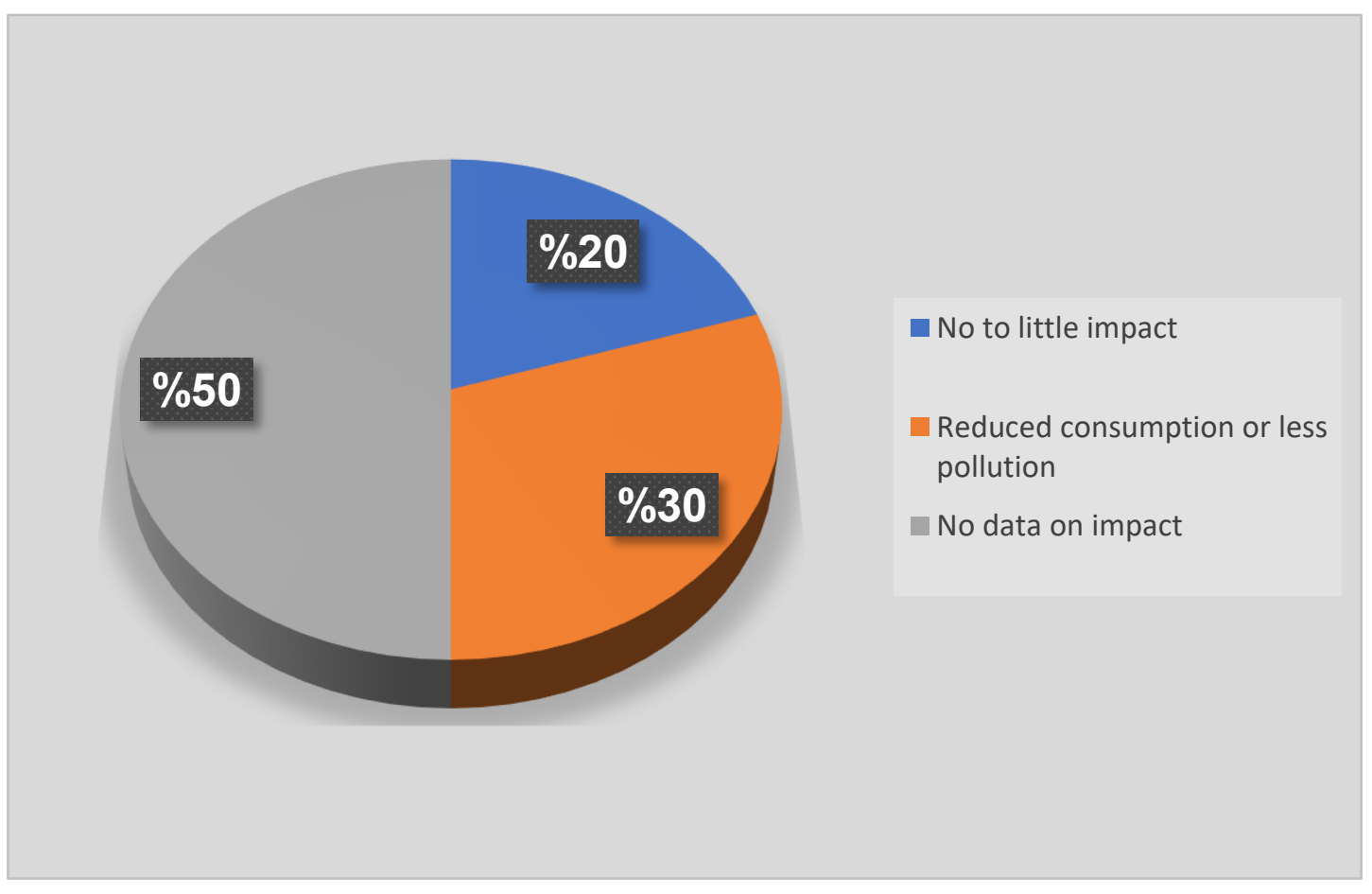

Figure 4. Impact of national bans and levies on plastic bag usage. Data from [18].

\section{Mismanagement of Plastic Waste}

In waste management, precedence ought to always be rendered to the prevention of waste. It is always wiser to prevent pollution today than to wait to handle the waste in the future. One localised study revealed that the majority of consumers were willing to reduce usage of plastic and adopt environmentally friendly packaging, however, their behaviour was contrary to their positive attitude placing blame on industry providing the disposable packaging [133]. Reduced plastic use and thus waste generation would result in reduction of mismanaged plastic waste $[62,134,135]$. Figure 5 shows the global share of plastic waste that was inadequately disposed as at 2010. Inadequately disposed plastic waste refers to all plastic waste that is not well contained in disposal points like in dumps or uncontrolled landfills [19]. This waste can easily migrate into the neighbouring environment and can easily find its way into oceans. This waste problem is a result of ineffective waste management systems $[19,136]$. 


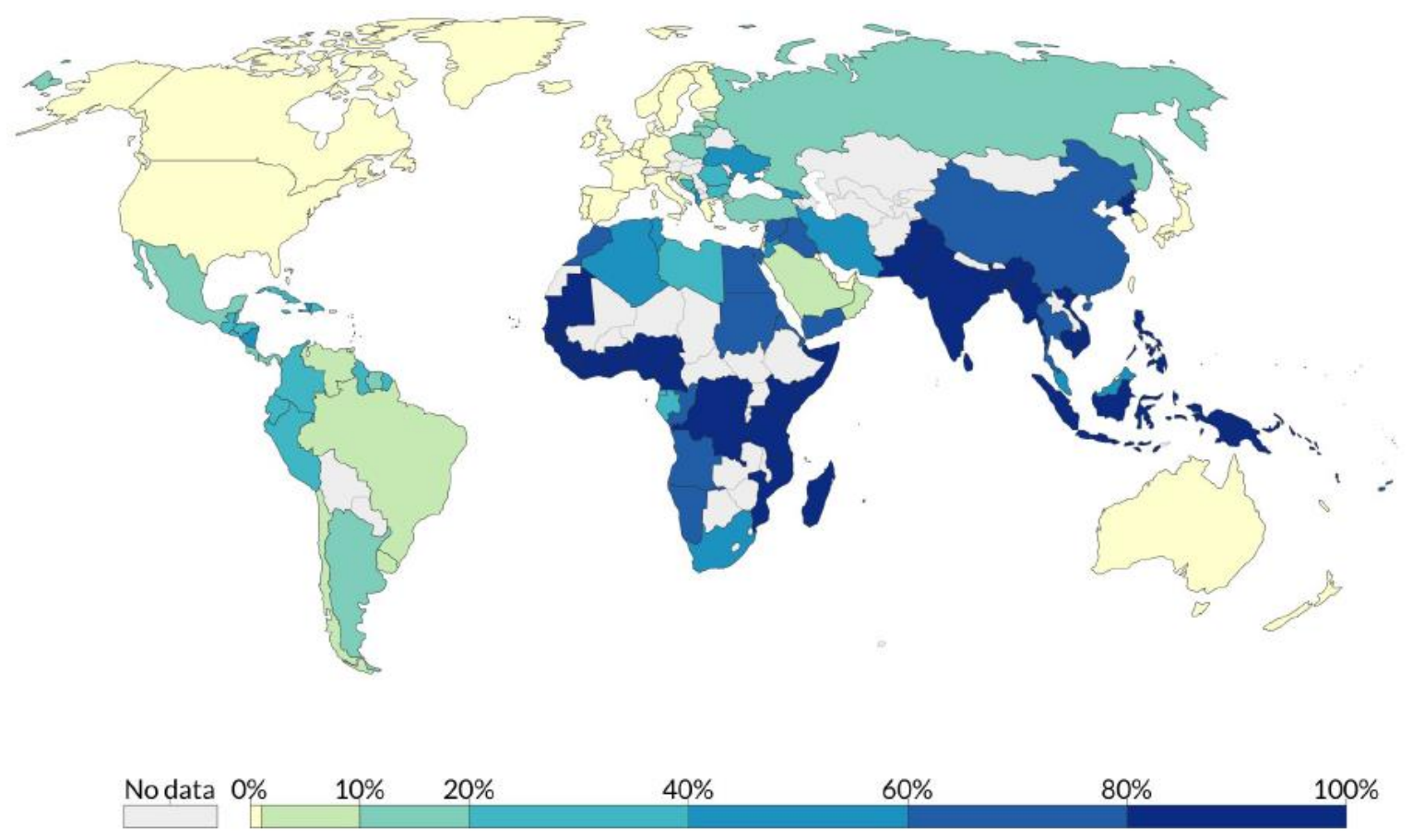

Figure 5. Inadequately disposed plastic waste as at 2010 [19] (Available online: https:/ / creativecommons.org/licenses / by / 4.0/ (accessed on 25 November 2020)).

It is reported by Maria and Leva [67] that developed countries have almost no inadequately managed plastic waste whilst countries in southeast Asia and the pacific are the chief culprits accounting for $60 \%$ of global inadequately managed plastics. Africa contributes a share of $17.2 \%$ with the Middle East and North Africa accounting for $8.3 \%$ and $8.9 \%$ for Sub-Saharan Africa (SSA). SSA is also reported to have $80-90 \%$ of plastic waste being inadequately disposed. A study by Lebreton and Andrady [137] reports that the increase in waste management infrastructure may not be enough for some parts of the world particularly in Africa. The projections of the study were up to the year 2060 and indicated that demand for plastic in Africa would grow by $375 \%$ of the current demand whilst the global average growth was pegged at $210 \%$.

\section{Plastic Waste in Africa}

The annual growth rate of plastic consumption in Africa is pegged at $2 \%$ and has the potential to reach over 20 million tonnes by 2025 [42]. However, there are a few studies that account for the plastic waste and waste management strategies in Africa. Additionally, there are not many reports on the extent of amount of waste entering the coastal and oceanic waters around Africa. However, the assumption is the models of pollution follow those of developing countries from other continents. Literature states that for developing countries, the management of environmental pollution from plastic waste poses a significant challenge [8,138-141]. It is reported that despite their efforts, recycled plastics account for only $10 \%$ of the total generated plastic waste [39]. Africa is reported to have limitations in plastic recycling capability and inefficient waste collection [142-144]. The accumulation of mismanaged plastic waste in the environment is said to remain unreasonably high in African and Asian continents even going into the foreseeable future [137]. The African population is reported to rely on plastic as a low-priced material for packaging [145]. Africa has been shown to be the chief driver of the growth in global population and this is seen to result in a huge market for plastics and consequently plastic waste [146]. The population growth is expected to rise from 1.34 billion as at 1 July 2020 to 2.19 billion in 2050 [147].

Plastics can be seen littering roads, footpaths, rivers, sewage systems and open spaces in towns and even in rural areas in African countries. This as a result of the throw away 
culture of consumers. Grazing animals like cattle, sheep and goats have been reported to die after eating plastic bags which became entangled in their stomachs [148]. In addition to land based sources of waste, Africa's shipping and maritime activities have mismanaged waste ensuing pollution in the oceans [146]. One study in the Mwanza region of Tanzania on fish from Lake Victoria had plastics identified in $20 \%$ of the fish from each species [149]. Current efforts in Africa are for limiting plastic use, however, there is still a need to also address plastic pollution already present. Rwanda took the lead by banning the use of nonbiodegradable polyethylene bags in 2008. Rwanda leading by example, has managed to successfully reduce plastic consumption by banning single use plastics, plastic bags and promoting the substituting of plastic construction material [150].

Africa is the only continent where the most countries introduced a total ban on the manufacture and use of plastic bags, with 25 countries having announced regulations on plastics, although more than $50 \%$ of them only started implementation as of 2014 [18]. This lack of strict enforcement of regulations of plastics should be reviewed and corrected. Additionally, Africa is said to lack stakeholder involvement in the drafting of plastic bans, limited consumer awareness, bans given without enough notice time and with no plastic substitutes [132]. Southern African countries comprise Angola, Botswana, Lesotho, Malawi, Mozambique, Namibia, South Africa, Eswatini, Zambia and Zimbabwe. As of 2018, only four southern African countries had introduced levies and bans to counter the effects resulting from plastic waste pollution. These are shown in Table 2. The chief culprit targeted is single-use plastic bags that are reported to have global annual consumption of up to 1 trillion bags that translate to 32,150 bags per second and most of these end in the environment soon after use [130,151-153]. This is because plastic bags are light weight and have a parachute-shaped design that makes them particularly challenging to manage as they can easily glide through the air and in waterways [154]. These plastic bags present a good surface area for photodegradation to form microplastics that do easily enter the human food chain. Microplastic have proved to serve as vectors facilitating the spread of various pollutants including persistent organic pollutants as these have high affinity towards microplastics [155].

Table 2. Table of summary of the southern region African countries that have introduced regulations on plastic bags and Styrofoam products. Adapted from [18].

\begin{tabular}{|c|c|c|c|c|}
\hline Country & Year & Level & Policy & Impact \\
\hline Botswana & 2007 & National & Levy on retailer for the use of plastic bags & $\begin{array}{l}\text { Decline in consumption of plastic bags } \\
\text { however pollution as a result of plastic } \\
\text { bags still persists }\end{array}$ \\
\hline Mozambique & 2016 & National & $\begin{array}{l}\text { Ban on the production, importation, sale } \\
\text { and distribution of plastic bags }\end{array}$ & No information available \\
\hline South Africa & 2003 & National & $\begin{array}{c}\text { Ban on plastic bags }<30 \mu \text { and levy on } \\
\text { retailer for thicker ones }\end{array}$ & Lack of enforcement \\
\hline \multirow[t]{2}{*}{ Zimbabwe } & 2010 & National & $\begin{array}{c}\text { Ban on plastic bags }<30 \mu \text { and levy on } \\
\text { consumer for thicker ones }\end{array}$ & $\begin{array}{c}\text { Resistance from the informal sector and } \\
\text { plastic bags smuggled in from } \\
\text { Mozambique }\end{array}$ \\
\hline & 2017 & National & Ban on Styrofoam products & No information available \\
\hline
\end{tabular}

\section{Circular Economy}

To effectively deal with waste, the old way of doing things following the "make, use and dispose" model should be abandoned for the sustainable "make, use, reuse and recycle" model $[49,70,124,156]$. Principles like extended producer responsibility have also catapulted forward the need for recycling of aftermarket waste [76]. Recycling ensures that post use materials are returned to the factory as raw material thereby forming a circular loop [25]. A circular economy thrives to prevent waste by conserving resources within the system. This is in resonance with the United Nations Sustainable Development Goal (SDG) number 12, which seeks to ensure sustainable consumption and production 
patterns [157]. Figure 6 illustrates the circularity of plastics that can be implemented by all nations to in a bid to accomplish sustainable management of plastics. The adoption of the circular economy concept in plastic management into the future would eventually mitigate the challenges faced by plastic waste problems particularly waste from plastic packaging $[8,23,133,158]$.

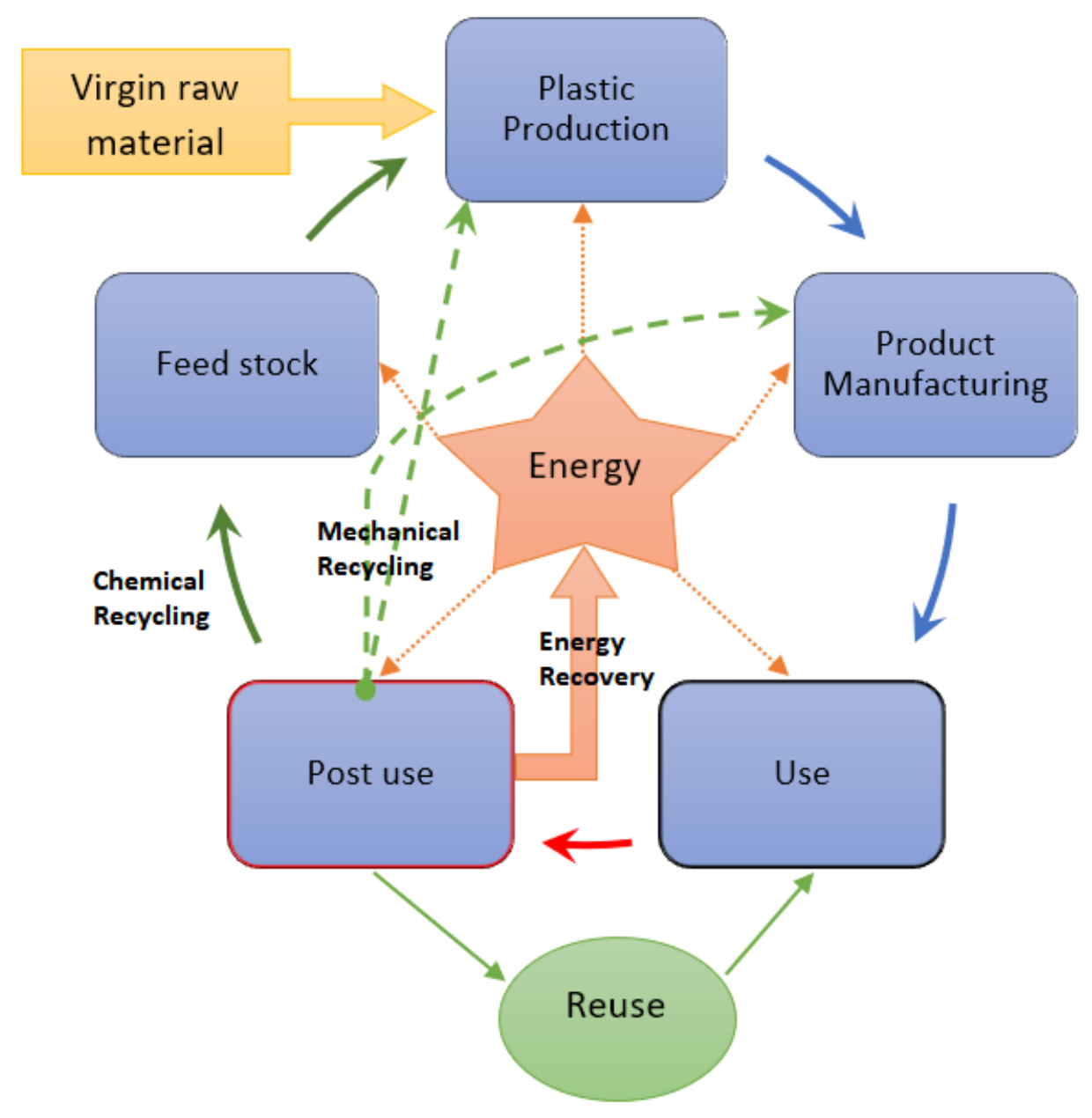

Figure 6. Plastics circular economy. Adapted from [12].

To achieve the closed-loop use of resources of a circular economy in plastic waste management, there should exist genuine cooperation between all sectors of a society. The following Figure 7 displays the relationship between the they players that can bring about real change.

The government plays the role of an overseer and is responsible for monitoring and gathering data on the production, use and disposal of plastics. This information can be used to draw up policies and design systems for waste reduction. Coupled with research on key issues, effective and sustainable policies can be developed that can give birth to a circular economy. A conceptual framework for the successful reverse logistics implementation to plastics recycling has been proposed by Tesfaye and Kitaw [78] to achieve a circular economy. 


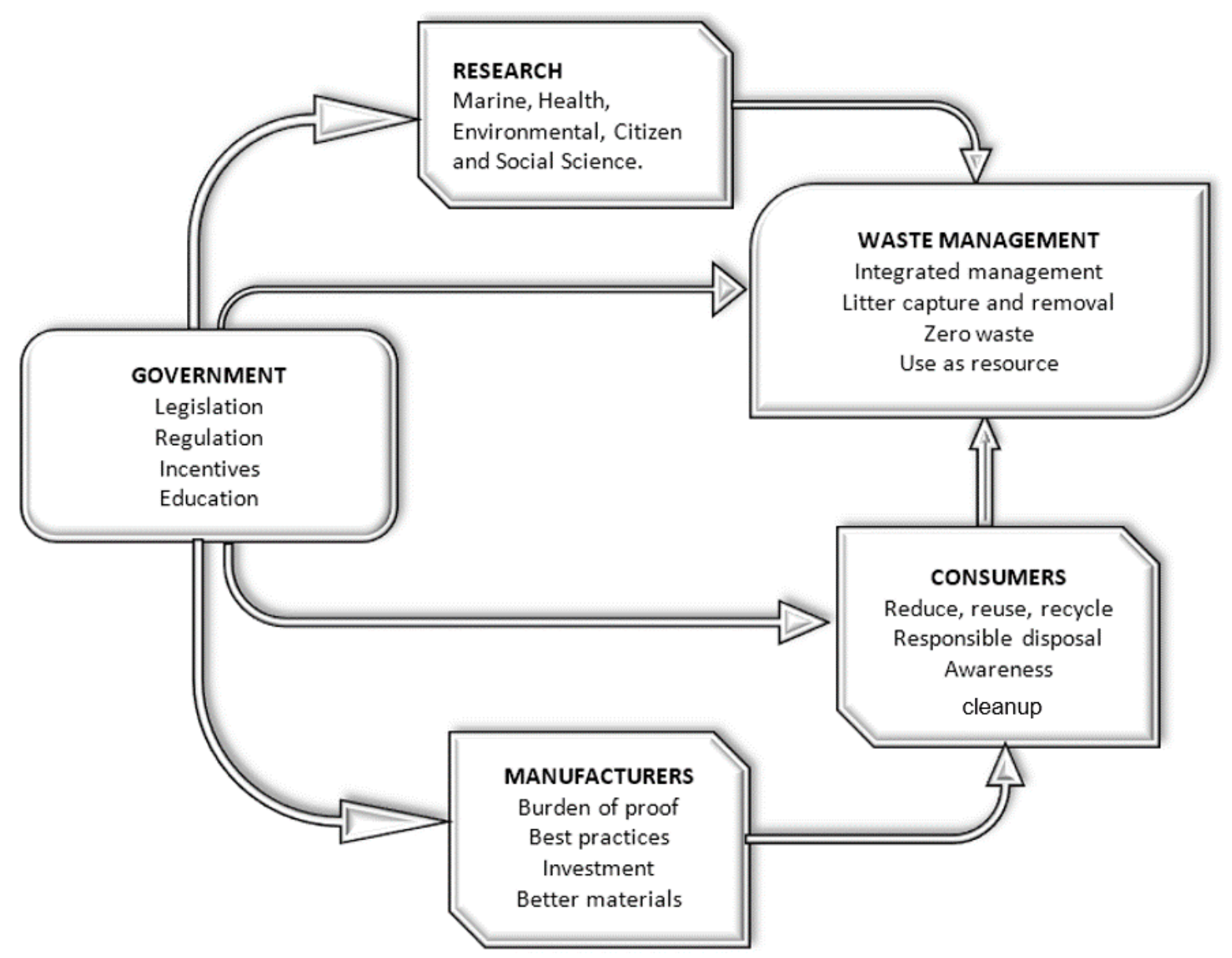

Figure 7. Cooperation between all sectors to curb plastic pollution. Adapted from [159].

\section{Future of Packaging Plastics}

In the current world, the need for recycling, recovery and management of plastic waste is of paramount importance [54]. Nations from around the world are now increasingly taking action and demonstrating that whether they are from a rich or poor nation, it is possible to be global environmental leaders. However, if they fail to cope it means with the current plastic management habits, by the year 2050 there would be 12 billion tonnes of plastic litter in the environment distributed across the land and water bodies [18]. These figures would mean the plastic industry will now be consuming $20 \%$ up from $8 \%$ of the global oil production. Plastics use was on the rise rapidly whilst no one was observant of the consequences resulting in an upsurge of mixed variable waste materials entering waste streams [160].

Governments have the most imperative part in curbing the problem of plastic waste going into the future. They should be in a position to finance basic and applied research to measure the up-to-date plastic problem and the hazards posed to human health and the environment [159]. The information collected should be packaged effectively to reach all target audiences to school and increase consciousness on the challenges presented by the use of plastics. This would also go a long way to alter the littering habit of humans and possibly bring it to an end. As a result, the volume of waste from food packaging plastic waste would be greatly reduced to manageable levels towards achieving zero waste.

Disposable packaging has become very popular for emerging economies resulting in adverse impacts on the environment which has caught the attention of the media. Media trends are showing that plastics are becoming a topic of interest giving rise to pressure on governments to adopt policies that demand a sustainable approach to plastic use 
and management. This increasing awareness of plastic pollution is giving rise to plastic recycling and innovations to address plastic challenges. As a result, this may lead to creation of new markets, jobs and manufacturing opportunities in the future [70].

Waste will continue to grow as a result of increasing world population and increased per capita consumption accompanying economic growth. This will be more realised in urban areas and developing African countries. High population growth in Africa is a driver for increased food consumption patterns that will raise demand for plastic packaging and thus an increase in plastic waste particularly single use food packaging. Drive should be towards investment in boosting the infrastructure responsible for managing waste in developing nations and this will make use of considerable resources and time [62]. Additionally, the lack of affordable alternatives needs to be thoroughly investigated and preferably long-lasting solutions would be provided by eco-friendly alternatives such as the use of biodegradable biopolymers for single use food packaging applications. Worldwide, governments are coming up with policies and legislations to promote usage of biopolymers in packaging [4]. African countries will also require widespread efforts to give birth to a continuous scrutiny and revision of policies meant to reduce or ban the use of single-use plastics [132].

China introduced an import policy ban on the importation of nonindustrial plastic waste which commenced on 1 January 2018. A study by Wang et al. [39] reported that China had been importing plastic waste since 1992 to manufacture goods for sale and export and many countries heavily relied on exporting their waste to China as an outlet for managing plastic waste. In 2016 alone, China imported 7.35 million tonnes from 43 countries which was about $50 \%$ of plastic waste exported by 123 countries intended for recycling. Cumulatively, China has imported $45.1 \%$ of total plastic waste exports. This ban on waste imports will have a cascading effect on the countries that were exporting waste for some years to come. Brooks et al. [160] reported that the most affected countries include the East Asia and Pacific, Europe and central Asia, and North America countries. Two outcomes may result from this ban which are plastic waste overwhelming some nations or the development of robust waste management systems that will bear fruits in the future.

The European Commission has already responded to this development. Some of the countries at the bold forefront are France and Germany, whose plastic packaging producers have already actively engaged value chain partners and invested in research and development of new plastic packaging. They have already signed a Circular Plastic Alliance and aim to have at least $90 \%$ of household packaging being recyclable or reusable by the year 2025 [161]. Several milestones are continuously being set in Europe for managing plastic waste. Targets were set for plastic packaging recycling to reach $50 \%$ by $2025,55 \%$ by 2030, and plastic bag bans and Styrofoam regulations [18]. It is hoped that by the year 2050 incineration rates will reach 50\%, recycling $44 \%$ and discarded waste $6 \%$ [19]. The (EU) 2018/852 directive on packaging and packaging waste also presented a new method of determining recycling performance set to commence with data from the year 2020. The "Plastics 2030" coined by the European Commission as a strategy for plastics in a circular economy is a voluntary commitment that is envisioned to transform the European Plastic industry to achieve a circular and resource efficient plastic economy. The envisioned plan is to have every packaging material on the continent be $100 \%$ reusable or recyclable with zero landfilling so as to achieve a circular economy of plastics [158]. It cannot be over emphasised that there is need for cooperation between all stake holders to achieve a plastic pollution free society.

It is also important to note the impact of the COVID-19 pandemic on the plastic industry. With social distancing measures in place, it means food consumption has been further promoted to be consumed on the go. Consumers who would have ideally ordered a sit in meal in their favourite restaurant are now forced to order a takeaway. These takeaway foods come contained in single-use food packaging plastics. After consumption, the packaging waste is now more likely to be mixed together with several other household waste materials rather than be sorted separately. This is because refuse collection rates 
have fallen, and curb side disposal has also been reduced leaving waste concentrated in households. In developed economies this may mean increased raw material for recycling plants whilst for developing countries temptations will be high to dispose of the waste into the surrounding environment increasing the amount of mismanaged waste. Studies have begun documenting this unique period with works from [162-167]. In the near future more studies on quantities, implications and trends of generated plastic waste quantities will be documented.

\section{Conclusions}

Plastics are still a consumer preference material for packaging solutions. They are the most produced material globally for different application markets including electronics, automotive, agriculture, toys and textiles. They have found high uptake in packaging industry particularly in the food industry where the packaging is mostly single-use. At the end of their very short useful lifetime, these plastics easily find their way into the environment. In the environment, plastics can negatively affect animal and human health as they pollute land and water bodies and even find their way into the food chain. This has resulted in a growing need to provide packaging material that is economic, convenient and environmentally sound. While the search for environmentally friendly packaging is ongoing, there is need to adopt the reduce, reuse and recycle model. Governments have to play the key role to regulate, businesses should innovate, institutions should research and individuals should act. Together, a working society can achieve a plastics circular economy with effective waste management systems to curb the pollution problem from plastic use. This will be particularly important in Africa as studies project that the continent would be the biggest consumer of food packaging plastic materials.

Author Contributions: L.K.N. and A.U.U. were responsible for conceptualization, methodology and original draft preparation. L.K.N., A.U.U., E.N.O., R.Z. and I.N.B. were responsible for validation, formal analysis, resources, review and editing. All authors have read and agreed to the published version of the manuscript.

Funding: This research received no external funding.

Acknowledgments: The authors appreciate the Botswana International University of Science and Technology (BIUST) for their role in ensuring the successful publication of this work.

Conflicts of Interest: The authors declare no conflict of interest.

\section{References}

1. Imam, S.; Glenn, G.; Chiellini, E. Utilization of biobased polymers in food packaging: Assessment of materials, production and commercialization. In Emerging Food Packaging Technologies; Elsevier: Amsterdam, The Netherlands, 2012; pp. $435-468$.

2. United Nations, Department of Economic and Social Affairs, Population Division. World Population Prospects 2019: Highlights; United Nations: New York, NY, USA, 2019.

3. Guillard, V.; Gaucel, S.; Fornaciari, C.; Angellier-Coussy, H.; Buche, P.; Gontard, N. The next generation of sustainable food packaging to preserve our environment in a circular economy context. Front. Nutr. 2018, 5, 121. [CrossRef] [PubMed]

4. Jacob, J.; Lawal, U.; Thomas, S.; Valapa, R.B. Chapter 4-Biobased polymer composite from poly(lactic acid): Processing, fabrication, and characterization for food packaging. In Processing and Development of Polysaccharide-Based Biopolymers for Packaging Applications; Zhang, Y., Ed.; Elsevier: Amsterdam, The Netherlands, 2020; pp. 97-115. [CrossRef]

5. Trinetta, V. Application of Packaging Systems for Different Food Products. In Reference Module in Food Science; Elsevier: Amsterdam, The Netherlands, 2016. [CrossRef]

6. Al-Salem, S.M.; Lettieri, P.; Baeyens, J. Recycling and recovery routes of plastic solid waste (PSW): A review. Waste Manag. 2009, 29, 2625-2643. [CrossRef]

7. Payne, J.; McKeown, P.; Jones, M.D. A circular economy approach to plastic waste. Polym. Degrad. Stab. 2019, 165, $170-181$. [CrossRef]

8. Horodytska, O.; Cabanes, A.; Fullana, A. Plastic Waste Management: Current Status and Weaknesses. In The Handbook of Environmental Chemistry; Stock, F., Reifferscheid, G., Brennholt, N., Kostianaia, E., Eds.; Springer: Heidelberg/Berlin, Germany, 2019; pp. 1-18.

9. European_Bioplastics. Bioplastics Facts and Figures. Available online: https://docs.european-bioplastics.org/publications/ EUBP_Facts_and_figures.pdf (accessed on 21 May 2020). 
10. Papadopoulou, E.L.; Paul, U.C.; Tran, T.N.; Suarato, G.; Ceseracciu, L.; Marras, S.; d'Arcy, R.; Athanassiou, A. Sustainable Active Food Packaging from Poly(lactic acid) and Cocoa Bean Shells. ACS Appl. Mater. Interfaces 2019, 11, 31317-31327. [CrossRef] [PubMed]

11. Rahimi, A.; García, J.M. Chemical recycling of waste plastics for new materials production. Nat. Rev. Chem. 2017, 1, 1-11. [CrossRef]

12. Aisbl, P. Plastics-the Facts 2018 an Analysis of European Plastics Production, Demand and Waste Data. 2018. Available online: https:/ / www.plasticseurope.org/en/resources/publications/619-plastics-facts-2018 (accessed on 25 November 2020).

13. Directive (EU) 2019/904 of the European Parliament and of the Council of 5 June 2019 on the reduction of the impact of certain plastic products on the environment. Off. J. Eur. Union 2019, 155, 1-19.

14. Thompson, R.C.; Moore, C.J.; Vom Saal, F.S.; Swan, S.H. Plastics, the environment and human health: Current consensus and future trends. Philos. Trans. R. Soc. B: Biol. Sci. 2009, 364, 2153-2166. [CrossRef]

15. Fobil, J.; Hogarh, J. The dilemmas of plastic wastes in a developing economy: Proposals for a sustainable management approach for Ghana. West Afr. J. Appl. Ecol. 2006, 10. [CrossRef]

16. Vimal, K.E.K.; Mathiyazhagan, K.; Agarwal, V.; Luthra, S.; Sivakumar, K. Analysis of barriers that impede the elimination of single-use plastic in developing economy context. J. Clean. Prod. 2020, 272, 122629. [CrossRef]

17. Andrady, A.L.; Neal, M.A. Applications and societal benefits of plastics. Philos. Trans. R. Soc. B Biol. Sci. 2009, 364, 1977-1984. [CrossRef]

18. UNEP. SINGLE-USE PLASTICS: A Roadmap for Sustainability; UNEP: Nairobi, Kenya, 2018.

19. Ritchie, H.; Roser, M. Plastic Pollution. Available online: https:/ / ourworldindata.org/plastic-pollution (accessed on 13 July 2020).

20. Geyer, R.; Jambeck, J.R.; Law, K.L. Production, use, and fate of all plastics ever made. Sci. Adv. 2017, 3, e1700782. [CrossRef]

21. Aarnio, T.; Hämäläinen, A. Challenges in packaging waste management in the fast food industry. Resour. Conserv. Recycl. 2008, 52, 612-621. [CrossRef]

22. Ragaert, K.; Delva, L.; Van Geem, K. Mechanical and chemical recycling of solid plastic waste. Waste Manag. 2017, 69, 24-58. [CrossRef] [PubMed]

23. Tencati, A.; Pogutz, S.; Moda, B.; Brambilla, M.; Cacia, C. Prevention policies addressing packaging and packaging waste: Some emerging trends. Waste Manag. 2016, 56, 35-45. [CrossRef] [PubMed]

24. Accorsi, R.; Cascini, A.; Cholette, S.; Manzini, R.; Mora, C. Economic and environmental assessment of reusable plastic containers: A food catering supply chain case study. Int. J. Prod. Econ. 2014, 152, 88-101. [CrossRef]

25. Sæter, F.; Alvarado, I.O.; Pettersen, I.N. Reuse principle for primary packaging circularity in the food system. In Proceedings of the DS 101: Proceedings of NordDesign 2020, Lyngby, Denmark, 12-14 August 2020; pp. 1-12.

26. Robertson, G.L. Food Packaging: Principles and Practice; CRC Press: Boca Raton, FL, USA, 2016.

27. Sydow, Z.; Bieńczak, K. The overview on the use of natural fibers reinforced composites for food packaging. J. Nat. Fibers 2018, 16, 1189-1200. [CrossRef]

28. Marsh, K.; Bugusu, B. Food packaging-Roles, materials, and environmental issues. J. Food Sci. 2007, 72, R39-R55. [CrossRef]

29. Robertson, G.L. Definitions, Functions, Attributes and Environments of Food Packaging. In Reference Module in Food Science; Elsevier: Amsterdam, The Netherlands, 2018. [CrossRef]

30. Welt, B. A Brief History of Packaging. Institute of Food and Agricultural Sciences, Document ABE321; University of Florida: Gainesville, FL, USA, 2005; Available online: https:/ / ufdc.ufl.edu/IR00001524/00001 (accessed on 25 November 2020).

31. Raheem, D. Application of plastics and paper as food packaging materials-An overview. Emir. J. Food Agric. 2013, 25, 177-188. [CrossRef]

32. Nurul Fazita, M.; Jayaraman, K.; Bhattacharyya, D.; Mohamad Haafiz, M.; Saurabh, C.K.; Hussin, M.H.; HPS, A.K. Green composites made of bamboo fabric and poly (lactic) acid for packaging applications-A review. Materials 2016, 9, 435. [CrossRef] [PubMed]

33. Ashok, A.; Rejeesh, C.; Renjith, R. Biodegradable polymers for sustainable packaging applications: A review. IJBB 2016, 1, 11.

34. Kumar, M.S.; Yaakob, Z. Biobased materials in food packaging applications. Handb. Bioplast. Biocompos. Eng. Appl. 2011, 81, 121-159.

35. Wikström, F.; Williams, H.; Verghese, K.; Clune, S. The influence of packaging attributes on consumer behaviour in food-packaging life cycle assessment studies-A neglected topic. J. Clean. Prod. 2014, 73, 100-108. [CrossRef]

36. Marsh, K.S. Polymer and Plastic Packaging. In Reference Module in Food Science; Elsevier: Amsterdam, The Netherlands, 2016. [CrossRef]

37. Jefferson, M. Whither Plastics?-Petrochemicals, plastics and sustainability in a garbage-riddled world. Energy Res. Soc. Sci. 2019, 56, 101229. [CrossRef]

38. Sardon, H.; Dove, A.P. Plastics recycling with a difference. Science 2018, 360, 380-381. [CrossRef] [PubMed]

39. Wang, W.; Themelis, N.J.; Sun, K.; Bourtsalas, A.C.; Huang, Q.; Zhang, Y.; Wu, Z. Current influence of China's ban on plastic waste imports. Waste Dispos. Sustain. Energy 2019, 1, 67-78. [CrossRef]

40. Narancic, T.; O'Connor, K.E. Plastic waste as a global challenge: Are biodegradable plastics the answer to the plastic waste problem? Microbiology 2019, 165, 129-137. [CrossRef] 
41. Kumar, G.M.; Irshad, A.; Raghunath, B.; Rajarajan, G. Waste management in food packaging industry. In Integrated Waste Management in India; Springer: Heidelberg/Berlin, Germany, 2016; pp. 265-277.

42. Biron, M. Thermoplastics and Thermoplastic Composites; William Andrew: Norwich, NY, USA, 2018.

43. Williams, K.S. Plastic Packaging: Not a Throw-away Resource. In Issues in Environmental Science and Technology: Waste as a Resource; The Royal Society for Chemistry: Cambridge, UK, 2013; pp. 83-109.

44. $\mathrm{Hu}, \mathrm{B}$. Biopolymer-based lightweight materials for packaging applications. In Lightweight Materials from Biopolymers and Biofibers; ACS Publications: Washington, DC, USA, 2014; pp. 239-255.

45. Porta, R.; Sabbah, M.; Di Pierro, P. Biopolymers as Food Packaging Materials. Int. J. Mol. Sci. 2020, 21, 4942. [CrossRef]

46. Pivnenko, K.; Eriksen, M.K.; Martín-Fernández, J.A.; Eriksson, E.; Astrup, T.F. Recycling of plastic waste: Presence of phthalates in plastics from households and industry. Waste Manag. 2016, 54, 44-52. [CrossRef] [PubMed]

47. Brown, D. Plastics packaging of food products: The environmental dimension. Trends Food Sci. Technol. 1993, 4, 294-300. [CrossRef]

48. European Commission. A European Strategy for Plastics in a Circular Economy; European Commission: Brussels, Belgium, 2018.

49. Lau, W.W.; Shiran, Y.; Bailey, R.M.; Cook, E.; Stuchtey, M.R.; Koskella, J.; Velis, C.A.; Godfrey, L.; Boucher, J.; Murphy, M.B. Evaluating scenarios toward zero plastic pollution. Science 2020, 369, 1455-1461. [CrossRef]

50. McDermott, K.L. Plastic Pollution and the Global Throwaway Culture: Environmental Injustices of Single-Use Plastic. 2016. Available online: https: / / www.semanticscholar.org/paper/Plastic-Pollution-and-the-Global-Throwaway-Culture\%3A-McDermott/ 1f5739852233d4c162994a919f058251b8196418?p2df (accessed on 25 November 2020).

51. Dauvergne, P. Why is the global governance of plastic failing the oceans? Glob. Environ. Chang. 2018, 51, 22-31. [CrossRef]

52. Hahladakis, J.N.; Iacovidou, E. Closing the loop on plastic packaging materials: What is quality and how does it affect their circularity? Sci. Total Environ. 2018, 630, 1394-1400. [CrossRef] [PubMed]

53. Chitaka, T.Y.; Russo, V.; von Blottnitz, H. In pursuit of environmentally friendly straws: A comparative life cycle assessment of five straw material options in South Africa. Int. J. Life Cycle Assess. 2020, 25, 1818-1832. [CrossRef]

54. Singh, N.; Hui, D.; Singh, R.; Ahuja, I.P.S.; Feo, L.; Fraternali, F. Recycling of plastic solid waste: A state of art review and future applications. Compos. Part B Eng. 2017, 115, 409-422. [CrossRef]

55. Nemat, B.; Razzaghi, M.; Bolton, K.; Rousta, K. The role of food packaging design in consumer recycling behavior-A literature review. Sustainability 2019, 11, 4350. [CrossRef]

56. Kumar, N.; Kaur, P.; Bhatia, S. Advances in bio-nanocomposite materials for food packaging: A review. Nutr. Food Sci. 2017, 47, 591-606. [CrossRef]

57. Toniolo, S.; Mazzi, A.; Niero, M.; Zuliani, F.; Scipioni, A. Comparative LCA to evaluate how much recycling is environmentally favourable for food packaging. Resour. Conserv. Recycl. 2013, 77, 61-68. [CrossRef]

58. Shah, A.A.; Hasan, F.; Hameed, A.; Ahmed, S. Biological degradation of plastics: A comprehensive review. Biotechnol. Adv. 2008, 26, 246-265. [CrossRef] [PubMed]

59. Grujić, R.; Vujadinović, D.; Savanović, D. Biopolymers as food packaging materials. In Advances in Applications of Industrial Biomaterials; Springer: New York, NY, USA, 2017; pp. 139-160.

60. Matsuguma, Y.; Takada, H.; Kumata, H.; Kanke, H.; Sakurai, S.; Suzuki, T.; Itoh, M.; Okazaki, Y.; Boonyatumanond, R.; Zakaria, M.P. Microplastics in sediment cores from Asia and Africa as indicators of temporal trends in plastic pollution. Arch. Environ. Contam. Toxicol. 2017, 73, 230-239. [CrossRef]

61. Adeyeye, O.; Sadiku, E.R.; Reddy, A.B.; Ndamase, A.S.; Makgatho, G.; Sellamuthu, P.S.; Perumal, A.B.; Nambiar, R.B.; Fasiku, V.O.; Ibrahim, I.D. The Use of Biopolymers in Food Packaging. In Green Biopolymers and Their Nanocomposites; Springer: New York, NY, USA, 2019; pp. 137-158.

62. Jambeck, J.R.; Geyer, R.; Wilcox, C.; Siegler, T.R.; Perryman, M.; Andrady, A.; Narayan, R.; Law, K.L. Plastic waste inputs from land into the ocean. Science 2015, 347, 768-771. [CrossRef]

63. Nesic, A.; Castillo, C.; Castaño, P.; Cabrera-Barjas, G.; Serrano, J. Chapter 8-Bio-based packaging materials. In Biobased Products and Industries; Galanakis, C.M., Ed.; Elsevier: Amsterdam, The Netherlands, 2020; pp. 279-309. [CrossRef]

64. Larissa Copello, D.S. Initiatives to Reduce the Production and Consumption of Plastics. 2019. Available online: https://www. 2030spotlight.org/en/book/1883/chapter/sdg-12-initiatives-reduce-production-and-consumption-plastics (accessed on 25 November 2020).

65. Calabrò, P.S.; Grosso, M. Bioplastics and waste management. Waste Manag. 2018, 78, 800-801. [CrossRef]

66. de Kock, L.; Sadan, Z.; Arp, R.; Upadhyaya, P. A circular economy response to plastic pollution: Current policy landscape and consumer perception. S. Afr. J. Sci. 2020, 116, 1-2. [CrossRef]

67. Maria Tsakona, I.R. Baseline Report on Plastic Waste. 2020. Available online: https://www.google.com.hk/url?sa=t\&rct= $\mathrm{j} \& \mathrm{q}=\&$ esrc=s\&source=web\&cd=\&ved=2ahUKEwik4v72r4buAhWVHHAKHQzdCT0QFjAAegQIAxAC\&url=https $\% 3 A \%$ 2F\%2Fgridarendal-website-live.s3.amazonaws.com\%2Fproduction\%2Fdocuments\%2F\%3As_document\%2F554\%2Foriginal\% 2FUNEP-CHW-PWPWG.1-INF-4.English.pdf\%3F1594295332\&usg=AOvVaw3zRwa3wvsliJmF6_eZIpcb (accessed on 25 November 2020).

68. Hopewell, J.; Dvorak, R.; Kosior, E. Plastics recycling: Challenges and opportunities. Philos. Trans. R. Soc. B Biol. Sci. 2009, 364, 2115-2126. [CrossRef] 
69. Popescu, P.A.; Popa, E.E.; Mitelut, A.C.; Popa, M.E. Development of recyclable and biodegradable food packaging materialsOpportunities and risks. Curr. Trends Nat. Sci. 2020, 9, 142-146. [CrossRef]

70. Kosior, E.; Mitchell, J. Chapter 6-Current industry position on plastic production and recycling. In Plastic Waste and Recycling; Letcher, T.M., Ed.; Academic Press: Cambridge, MA, USA, 2020; pp. 133-162. [CrossRef]

71. Thiounn, T.; Smith, R.C. Advances and approaches for chemical recycling of plastic waste. J. Polym. Sci. 2020, 58, 1347-1364. [CrossRef]

72. Merrington, A. 9-Recycling of Plastics. In Applied Plastics Engineering Handbook, 2nd ed.; Kutz, M., Ed.; William Andrew Publishing: Norwich, NY, USA, 2017; pp. 167-189. [CrossRef]

73. Grigore, M.E. Methods of recycling, properties and applications of recycled thermoplastic polymers. Recycling 2017, 2, 24. [CrossRef]

74. Davis, G.; Song, J.H. Biodegradable packaging based on raw materials from crops and their impact on waste management. Ind. Crops Prod. 2006, 23, 147-161. [CrossRef]

75. López de Dicastillo, C.; Velásquez, E.; Rojas, A.; Guarda, A.; Galotto, M.J. The use of nanoadditives within recycled polymers for food packaging: Properties, recyclability, and safety. Compr. Rev. Food Sci. Food Saf. 2020, 19, 1760-1776. [CrossRef]

76. Cimpan, C.; Maul, A.; Jansen, M.; Pretz, T.; Wenzel, H. Central sorting and recovery of MSW recyclable materials: A review of technological state-of-the-art, cases, practice and implications for materials recycling. J. Environ. Manag. 2015, 156, 181-199. [CrossRef]

77. Zulkifley, M.A.; Mustafa, M.M.; Hussain, A. Probabilistic white strip approach to plastic bottle sorting system. In Proceedings of the 2013 IEEE International Conference on Image Processing, Melbourne, Australia, 15-18 September 2013; pp. 3162-3166. [CrossRef]

78. Tesfaye, W.; Kitaw, D. Conceptualizing reverse logistics to plastics recycling system. Soc. Responsib. J. 2020. [CrossRef]

79. Compagno, F. Recycling 2020-Reduce, Reuse, and Recycle: The case Terracina-Filomena Compagno-Terracina Zero Waste activist, Italy. J. Nucl. Energy Power Gener. Technol. 2020, 4, 1-2.

80. Eriksen, M.K.; Astrup, T.F. Characterisation of source-separated, rigid plastic waste and evaluation of recycling initiatives: Effects of product design and source-separation system. Waste Manag. 2019, 87, 161-172. [CrossRef] [PubMed]

81. Nemat, B.; Razzaghi, M.; Bolton, K.; Rousta, K. The Potential of Food Packaging Attributes to Influence Consumers' Decisions to Sort Waste. Sustainability 2020, 12, 2234. [CrossRef]

82. Woidasky, J.; Schmidt, J.; Auer, M.; Sander, I.; Schau, A.; Moesslein, J.; Wendler, P.; Kirchenbauer, D.; Wacker, D.; Gao, G. Photoluminescent Tracer Effects on Thermoplastic Polymer Recycling. In Advances in Polymer Processing 2020; Hopmann, C., Dahlmann, R., Eds.; Springer: Berlin/Heidlberg, Germany, 2020; pp. 1-13. [CrossRef]

83. Siracusa, V.; Ingrao, C.; Lo Giudice, A.; Mbohwa, C.; Dalla Rosa, M. Environmental assessment of a multilayer polymer bag for food packaging and preservation: An LCA approach. Food Res. Int. 2014, 62, 151-161. [CrossRef]

84. Del Borghi, A.; Parodi, S.; Moreschi, L.; Gallo, M. Sustainable packaging: An evaluation of crates for food through a life cycle approach. Int. J. Life Cycle Assess. 2020, 1-14. [CrossRef]

85. Siracusa, V.; Rocculi, P.; Romani, S.; Dalla Rosa, M. Biodegradable polymers for food packaging: A review. Trends Food Sci. Technol. 2008, 19, 634-643. [CrossRef]

86. Tajik, S.; Maghsoudlou, Y.; Khodaiyan, F.; Jafari, S.M.; Ghasemlou, M.; Aalami, M. Soluble soybean polysaccharide: A new carbohydrate to make a biodegradable film for sustainable green packaging. Carbohydr. Polym. 2013, 97, 817-824. [CrossRef]

87. Tapia-Blácido, D.R.; da Silva Ferreira, M.E.; Aguilar, G.J.; Lemos Costa, D.J. Chapter 9-Biodegradable packaging antimicrobial activity. In Processing and Development of Polysaccharide-Based Biopolymers for Packaging Applications; Zhang, Y., Ed.; Elsevier: Amsterdam, The Netherlands, 2020; pp. 207-238. [CrossRef]

88. Scarfato, P.; Di Maio, L.; Incarnato, L. Recent advances and migration issues in biodegradable polymers from renewable sources for food packaging. J. Appl. Polym. Sci. 2015, 132. [CrossRef]

89. Wróblewska-Krepsztul, J.; Rydzkowski, T.; Borowski, G.; Szczypiński, M.; Klepka, T.; Thakur, V.K. Recent progress in biodegradable polymers and nanocomposite-based packaging materials for sustainable environment. Int. J. Polym. Anal. Charact. 2018, 23, 383-395. [CrossRef]

90. Haider, T.P.; Völker, C.; Kramm, J.; Landfester, K.; Wurm, F.R. Plastics of the future? The impact of biodegradable polymers on the environment and on society. Angew. Chem. Int. Ed. 2019, 58, 50-62. [CrossRef]

91. Kabir, E.; Kaur, R.; Lee, J.; Kim, K.-H.; Kwon, E.E. Prospects of biopolymer technology as an alternative option for non-degradable plastics and sustainable management of plastic wastes. J. Clean. Prod. 2020, 258, 120536. [CrossRef]

92. Lambert, S.; Wagner, M. Environmental performance of bio-based and biodegradable plastics: The road ahead. Chem. Soc. Rev. 2017, 46, 6855-6871. [CrossRef]

93. Moustafa, H.; Youssef, A.M.; Darwish, N.A.; Abou-Kandil, A.I. Eco-friendly polymer composites for green packaging: Future vision and challenges. Compos. Part B Eng. 2019, 172, 16-25. [CrossRef]

94. Claro, P.; Neto, A.; Bibbo, A.; Mattoso, L.; Bastos, M.; Marconcini, J. Biodegradable blends with potential use in packaging: A comparison of PLA/chitosan and PLA/cellulose acetate films. J. Polym. Environ. 2016, 24, 363-371. [CrossRef]

95. Malik, N.; Kumar, P.; Shrivastava, S.; Ghosh, S.B. An overview on PET waste recycling for application in packaging. Int. J. Plast. Technol. 2017, 21, 1-24. [CrossRef] 
96. Arvanitoyannis, I.S.; Kasaveti, A. 7-Consumer attitude to food packaging and the market for environmentally compatible products. In Environmentally Compatible Food Packaging; Chiellini, E., Ed.; Woodhead Publishing: Cambridge, UK, 2008 ; pp. 161-181. [CrossRef]

97. Gardas, B.B.; Raut, R.D.; Narkhede, B. Identifying critical success factors to facilitate reusable plastic packaging towards sustainable supply chain management. J. Environ. Manag. 2019, 236, 81-92. [CrossRef] [PubMed]

98. Popović, S.; Jurečić, D.; Jezdić, B. Multifunctional, reusable X-Bin container. Polytech. Des. 2020, 8, 47-51.

99. Bortolini, M.; Galizia, F.G.; Mora, C.; Botti, L.; Rosano, M. Bi-objective design of fresh food supply chain networks with reusable and disposable packaging containers. J. Clean. Prod. 2018, 184, 375-388. [CrossRef]

100. Agyeman, S.; Obeng-Ahenkora, N.K.; Assiamah, S.; Twumasi, G. Exploiting recycled plastic waste as an alternative binder for paving blocks production. Case Stud. Constr. Mater. 2019, 11, e00246. [CrossRef]

101. Saheri, S.; Basri, N.A.; Mir, M.A.; Setoodehnia, P. Evaluation of energy production from domestic waste in Malaysia. In Proceedings of the 2nd International Conference on Environmental Research and Technology (ICERT 2010: Research and innovation towards environmental sustainability), Penang, Malaysia, 2-4 June 2010; pp. 408-412.

102. Tiew, K.-G.; Watanabe, K.; Basri, N.E.A.; Basri, H. Composition of solid waste in a university campus and its potential for composting. Int. J. Adv. Sci. Eng. Inf. Technol. 2011, 1, 675-678. [CrossRef]

103. Al Qattan, N.; Acheampong, M.; Jaward, F.M.; Ertem, F.C.; Vijayakumar, N.; Bello, T. Reviewing the potential of Waste-to-Energy (WTE) technologies for Sustainable Development Goal (SDG) numbers seven and eleven. Renew. Energy Focus 2018, 27, 97-110. [CrossRef]

104. Panda, A.K.; Singh, R.K.; Mishra, D.K. Thermolysis of waste plastics to liquid fuel: A suitable method for plastic waste management and manufacture of value added products-A world prospective. Renew. Sustain. Energy Rev. 2010, 14, 233-248. [CrossRef]

105. da Silva, D.J.; Wiebeck, H. Current options for characterizing, sorting, and recycling polymeric waste. Prog. Rubber Plast. Recycl. Technol. 2020, 36, 284-303. [CrossRef]

106. Hahladakis, J.N.; Velis, C.A.; Weber, R.; Iacovidou, E.; Purnell, P. An overview of chemical additives present in plastics: Migration, release, fate and environmental impact during their use, disposal and recycling. J. Hazard. Mater. 2018, 344, 179-199. [CrossRef]

107. Tacito, L. Polymer Recycling Technology for Food-Use Technical Requirements to Meet Safety and Quality Assurance; ACS Publications: Washington, DC, USA, 1995; pp. 488-500.

108. Clark, S.; Jung, S.; Lamsal, B. Food Processing: Principles and Applications; John Wiley \& Sons: Hoboken, NJ, USA, 2014.

109. Kaur, G.; Uisan, K.; Ong, K.L.; Ki Lin, C.S. Recent Trends in Green and Sustainable Chemistry \& Waste Valorisation: Rethinking Plastics in a circular economy. Curr. Opin. Green Sustain. Chem. 2018, 9, 30-39. [CrossRef]

110. Franz, R.; Welle, F. Contamination Levels in Recollected PET Bottles from Non-Food Applications and their Impact on the Safety of Recycled PET for Food Contact. Molecules 2020, 25, 4998. [CrossRef] [PubMed]

111. Gabriel, D.S. How to increase plastic waste acceptance for mechanical recycling: An introduction to material value conservation and its phenomenon. In Proceedings of the 6th International Conference on Key Engineering Materials (ICKEM 2016), Hong Kong, China, 12-14 March 2016; pp. 362-367.

112. Xanthos, M. Recycling of the\# 5 polymer. Science 2012, 337, 700-702.

113. Dodbiba, G.; Sadaki, J.; Okaya, K.; Shibayama, A.; Fujita, T. The use of air tabling and triboelectric separation for separating a mixture of three plastics. Miner. Eng. 2005, 18, 1350-1360. [CrossRef]

114. Luijsterburg, B.; Goossens, H. Assessment of plastic packaging waste: Material origin, methods, properties. Resour. Conserv. Recycl. 2014, 85, 88-97. [CrossRef]

115. Masmoudi, F.; Alix, S.; Buet, S.; Mehri, A.; Bessadok, A.; Jaziri, M.; Ammar, E. Design and Characterization of a New Food Packaging Material by Recycling Blends Virgin and Recovered polyethylene terephthalate. Polym. Eng. Sci. 2020, 60, 250-256. [CrossRef]

116. Guillermo, A.; Noa, S. Potential effects of biodegradable single-use items in the sea: Polylactic acid (PLA) and solitary ascidians. Environ. Pollut. 2020. [CrossRef]

117. Ncube, L.K.; Ude, A.U.; Ogunmuyiwa, E.N.; Zulkifli, R.; Beas, I.N. Environmental Impact of Food Packaging Materials: A Review of Contemporary Development from Conventional Plastics to Polylactic Acid Based Materials. Materials 2020, 13, 4994. [CrossRef]

118. Farah, S.; Anderson, D.G.; Langer, R. Physical and mechanical properties of PLA, and their functions in widespread applicationsA comprehensive review. Adv. Drug Deliv. Rev. 2016, 107, 367-392. [CrossRef] [PubMed]

119. Castro-Aguirre, E.; Auras, R.; Selke, S.; Rubino, M.; Marsh, T. Enhancing the biodegradation rate of poly(lactic acid) films and PLA bio-nanocomposites in simulated composting through bioaugmentation. Polym. Degrad. Stab. 2018, 154, 46-54. [CrossRef]

120. Chamas, A.; Moon, H.; Zheng, J.; Qiu, Y.; Tabassum, T.; Jang, J.H.; Abu-Omar, M.; Scott, S.L.; Suh, S. Degradation Rates of Plastics in the Environment. ACS Sustain. Chem. Eng. 2020, 8, 3494-3511. [CrossRef]

121. Drzyzga, O.; Prieto, A. Plastic waste management, a matter for the 'community'. Microb. Biotechnol. 2018, 12, 66-68. [CrossRef] [PubMed]

122. Al-Salem, S.M.; Antelava, A.; Constantinou, A.; Manos, G.; Dutta, A. A review on thermal and catalytic pyrolysis of plastic solid waste (PSW). J. Environ. Manag. 2017, 197, 177-198. [CrossRef] [PubMed] 
123. Mir, M.A.; Basri, N.E.A.; Begum, R.A.; Saheri, S. Considering and forecasting of producing refuse derived fuel from Municipal Solid Waste in Malaysia by 2020. In Proceedings of the 2nd International Conference on Environmental Research and Technology (ICERT 2010: Research and innovation towards environmental sustainability), Penang, Malaysia, 2-4 June 2010; pp. 413-418.

124. Ferronato, N.; Torretta, V. Waste mismanagement in developing countries: A review of global issues. Int. J. Environ. Res. Public Health 2019, 16, 1060. [CrossRef] [PubMed]

125. Carp, B.G.; Mocanu, G.; Ion, I.V.; Popescu, F. Energy from municipal solid wastes: Galati city case study. In Proceedings of the E3S Web of Conferences, Sozopol, Bulgaria, 19-21 September 2020; Volume 207, p. 02001. [CrossRef]

126. Rafey, A.; Prabhat, K.; Samar, M. Comparison of Technologies to Serve Waste to Energy Conversion. Int. J. Waste Resour. 2020, 10, 372.

127. Moya, D.; Aldás, C.; Jaramillo, D.; Játiva, E.; Kaparaju, P. Waste-To-Energy Technologies: An opportunity of energy recovery from Municipal Solid Waste, using Quito-Ecuador as case study. Energy Procedia 2017, 134, 327-336. [CrossRef]

128. Makarichi, L.; Kan, R.; Jutidamrongphan, W.; Techato, K.-a. Suitability of municipal solid waste in African cities for thermochemical waste-to-energy conversion: The case of Harare Metropolitan City, Zimbabwe. Waste Manag. Res. 2019, 37, 83-94. [CrossRef] [PubMed]

129. Rochman, C.M.; Browne, M.A.; Halpern, B.S.; Hentschel, B.T.; Hoh, E.; Karapanagioti, H.K.; Rios-Mendoza, L.M.; Takada, H.; Teh, S.; Thompson, R.C. Classify plastic waste as hazardous. Nature 2013, 494, 169-171. [CrossRef] [PubMed]

130. Xanthos, D.; Walker, T.R. International policies to reduce plastic marine pollution from single-use plastics (plastic bags and microbeads): A review. Mar. Pollut. Bull. 2017, 118, 17-26. [CrossRef] [PubMed]

131. UNEP. Single-Use Plastics: A Roadmap for Sustainability. In Plásticos de un Solo Uso: Una Hoja de Ruta para la Sostenibilidad; UNEP: Nairobi, Kenya, 2018.

132. Adam, I.; Walker, T.R.; Bezerra, J.C.; Clayton, A. Policies to reduce single-use plastic marine pollution in West Africa. Mar. Policy 2020, 116, 103928. [CrossRef]

133. Dilkes-Hoffman, L.S.; Pratt, S.; Laycock, B.; Ashworth, P.; Lant, P.A. Public attitudes towards plastics. Resour. Conserv. Recycl. 2019, 147, 227-235. [CrossRef]

134. Van Rensburg, M.L.; Nkomo, S.p.L.; Dube, T. The 'plastic waste era'; social perceptions towards single-use plastic consumption and impacts on the marine environment in Durban, South Africa. Appl. Geogr. 2020, 114, 102132. [CrossRef]

135. Tiew, K.-G.; Basri, N.E.A.; Ahmad, I.K.; Basri, H. Solid waste management issues at Universiti Kebangsaan Malaysia. In Proceedings of the International Conference on Environmental Research and Technology (ICERT 2010): Research and Innovation towards Environmental Sustainability, Penang, Malaysia, 2-4 June 2010; pp. 705-709.

136. Al Mamun, M.A.; Hannan, M.; Hussain, A. A Novel Prototype and Simulation Model for Real Time Solid Waste Bin Monitoring System. J. Kejuruter. 2014, 26, 15-19. [CrossRef]

137. Lebreton, L.; Andrady, A. Future scenarios of global plastic waste generation and disposal. Palgrave Commun. 2019, 5, 1-11. [CrossRef]

138. Godfrey, L. Waste plastic, the challenge facing developing countries—ban it, change it, collect it? Recycling 2019, 4, 3. [CrossRef]

139. Gwada, B.; Ogendi, G.; Makindi, S.; Trott, S. Composition of plastic waste discarded by households and its management approaches. Glob. J. Environ. Sci. 2019, 5, 83-94.

140. Ryberg, M.W.; Hauschild, M.Z.; Wang, F.; Averous-Monnery, S.; Laurent, A. Global environmental losses of plastics across their value chains. Resour. Conserv. Recycl. 2019, 151, 104459. [CrossRef]

141. Ferronato, N.; Torretta, V.; Ragazzi, M.; Rada, E.C. Waste mismanagement in developing countries: A case study of environmental contamination. UPB Sci. Bull. 2017, 79, 185-196.

142. Adebiyi-Abiola, B.; Assefa, S.; Sheikh, K.; García, J.M. Cleaning up plastic pollution in Africa. Science 2019, 365, $1249-1251$. [CrossRef] [PubMed]

143. Mbiba, B. Urban solid waste characteristics and household appetite for separation at source in Eastern and Southern Africa. Habitat Int. 2014, 43, 152-162. [CrossRef]

144. Scarlat, N.; Motola, V.; Dallemand, J.F.; Monforti-Ferrario, F.; Mofor, L. Evaluation of energy potential of Municipal Solid Waste from African urban areas. Renew. Sustain. Energy Rev. 2015, 50, 1269-1286. [CrossRef]

145. Kutten, K. The Potential of Africa's Plastic Market and Its Impact on Plastic Waste Management. Master's Thesis, Lappeenranta University of Technology, Lappeenranta, Finland, 2019.

146. Jambeck, J.; Hardesty, B.D.; Brooks, A.L.; Friend, T.; Teleki, K.; Fabres, J.; Beaudoin, Y.; Bamba, A.; Francis, J.; Ribbink, A.J. Challenges and emerging solutions to the land-based plastic waste issue in Africa. Mar. Policy 2018, 96, 256-263. [CrossRef]

147. Kaba, A.J. Explaining Africa's Rapid Population Growth, 1950 to 2020: Trends, Factors, Implications, and Recommendations. Sociol. Mind 2020, 10, 226-268. [CrossRef]

148. Bashir, N.H. Plastic problem in Africa. Jpn. J. Vet. Res. 2013, 61, S1-S11.

149. Biginagwa, F.J.; Mayoma, B.S.; Shashoua, Y.; Syberg, K.; Khan, F.R. First evidence of microplastics in the African Great Lakes: Recovery from Lake Victoria Nile perch and Nile tilapia. J. Great Lakes Res. 2016, 42, 146-149. [CrossRef]

150. Babayemi, J.O.; Nnorom, I.C.; Osibanjo, O.; Weber, R. Ensuring sustainability in plastics use in Africa: Consumption, waste generation, and projections. Environ. Sci. Eur. 2019, 31, 60. [CrossRef]

151. O'Brien, J.; Thondhlana, G. Plastic bag use in South Africa: Perceptions, practices and potential intervention strategies. Waste Manag. 2019, 84, 320-328. [CrossRef] [PubMed] 
152. Mogomotsi, P.K.; Mogomotsi, G.E.; Phonchi, N.D. Plastic bag usage in a taxed environment: Investigation on the deterrent nature of plastic levy in Maun, Botswana. Waste Manag. Res. 2019, 37, 20-25. [CrossRef] [PubMed]

153. Rayne, S. The need for reducing plastic shopping bag use and disposal in Africa. Afr. J. Environ. Sci. Technol. 2008, 2. Available online: https://www.ajol.info/index.php/ajest/article/download/135418/124910 (accessed on 25 November 2020).

154. Knoblauch, D.; Mederake, L.; Stein, U. Developing countries in the lead-What drives the diffusion of plastic bag policies? Sustainability 2018, 10, 1994. [CrossRef]

155. Hartmann, N.B.; Rist, S.; Bodin, J.; Jensen, L.H.; Schmidt, S.N.; Mayer, P.; Meibom, A.; Baun, A. Microplastics as vectors for environmental contaminants: Exploring sorption, desorption, and transfer to biota. Integr. Environ. Assess. Manag. 2017, 13, 488-493. [CrossRef] [PubMed]

156. Yaacob, M.; Ibrahim, M.H.; Nasir, Z.M. Solid Waste Management in Malaysia: The Perspectives of Non-governmental Organizations (NGOs) and Youths on Consumers' Commitment. In Environmental Sustainability and Education for Waste Management; Springer: Heidelberg/Berlin, Germany, 2019; pp. 27-41.

157. United Nations. Transforming our world: The 2030 Agenda for Sustainable Development. In Division for Sustainable Development Goals; UN: New York, NY, USA, 2015.

158. Plastics_Europe. Plastics-The Facts: An Analysis of European Plastics Production, Demand and Waste Data; Plastics Europe: Brussels, Belgium, 2019.

159. Worm, B.; Lotze, H.K.; Jubinville, I.; Wilcox, C.; Jambeck, J. Plastic as a persistent marine pollutant. Annu. Rev. Environ. Resour. 2017, 42, 1-26. [CrossRef]

160. Brooks, A.L.; Wang, S.; Jambeck, J.R. The Chinese import ban and its impact on global plastic waste trade. Sci. Adv. 2018, 4, eaat0131. [CrossRef]

161. European_Commission. Joint Statement of the Plastics Packaging Industry in France and Germany on the Circular Economy Action Plan. 11 March 2020. Available online: https://newsroom.kunststoffverpackungen.de/wp-content/uploads/2020/06/ joint_statement_circular_economy_action.pdf (accessed on 25 November 2020).

162. Adyel, T.M. Accumulation of plastic waste during COVID-19. Science 2020, 369, 1314-1315. [PubMed]

163. Mohammad, A.; Goli, V.S.N.S.; Singh, D.N. Discussion on 'Challenges, opportunities, and innovations for effective solid waste management during and post COVID-19 pandemic, by Sharma et al. (2020)'. Resour. Conserv. Recycl. 2020, 164, 105175. [CrossRef] [PubMed]

164. Tabish, M.; Khatoon, A.; Alkahtani, S.; Alkahtane, A.; Alghamdi, J.; Ahmed, S.A.; Mir, S.S.; Albasher, G.; Almeer, R.; Al-Sultan, N.K. Approaches for prevention and environmental management of novel COVID-19. Environ. Sci. Pollut. Res. 2020, 1-11. [CrossRef] [PubMed]

165. Dean, R. PPE: Polluting Planet Earth. Br. Dent. J. 2020, 229, 267. [CrossRef] [PubMed]

166. Kahlert, S.; Bening, C.R. Plastics recycling after the global pandemic: Resurgence or regression? Resour. Conserv. Recycl. 2020, 160, 104948. [CrossRef] [PubMed]

167. Patrício Silva, A.L.; Prata, J.C.; Walker, T.R.; Campos, D.; Duarte, A.C.; Soares, A.M.V.M.; Barcelò, D.; Rocha-Santos, T. Rethinking and optimising plastic waste management under COVID-19 pandemic: Policy solutions based on redesign and reduction of single-use plastics and personal protective equipment. Sci. Total Environ. 2020, 742, 140565. [CrossRef] [PubMed] 